\title{
Democracia traicionada
}

\author{
Jorge Alonso
}

Las elecciones jaliscienses de 2006 fueron determinantes para el resultado de las elecciones presidenciales y para un tercer periodo consecutivo en el gobierno del estado. En el artículo se visualizan las campañas, la guerra sucia, las encuestas, los gastos partidistas y las impugnaciones. Se destaca lo sucedido en el recuento parcial de votos de la elección presidencial y se incursiona en la grave crisis electoral mexicana desde un observatorio regional.

PALABRAS CLAVE: democracia, partidos, campañas electorales, voto, impugnaciones

The 2006 general election in Jalisco, which resulted in the reelection of the incumbent party for a third consecutive term, played a decisive role in the presidential election. This paper analyzes the campaigns, the slander tactics, the polls, the parties' expenditures and the legal challenges filed against the official results. It also highlights the partial recount of the presidential election and deals with Mexico's severe electoral crisis from a regional standpoint.

KEYWORDS: Democracy, parties, electoral campaigns, voting, legal challenges

JORGE ALONSO: Centro de Investigaciones y Estudios Superiores en Antropología Social-Occidente, Guadalajara, México. jalonso@ciesasoccidente.edu.mx 


\section{INTRODUCCIÓN}

$\mathrm{L}$ as elecciones federales y locales en el estado de Jalisco en 2006 fueron relevantes para el resultado presidencial y para refrendar y aun incrementar el predominio panista en esa entidad. Por segunda ocasión fueron concurrentes debido a que el mismo día se realizaron las elecciones federales y las locales. En 2003 se eligieron diputados y munícipes, pero en 2006, además, se realizaron las elecciones presidenciales y para gobernador. Fue el estado en donde el candidato presidencial panista, Felipe Calderón, obtuvo una gran cantidad de votos, determinantes para su exiguo margen de ventaja. Se esperaba que en el caso de la elección de gobernador hubiera un voto de castigo por el mal gobierno del panismo; sin embargo, lo que se dio fue una ratificación. Hay que intentar esclarecer qué sucedió en estas elecciones.

El gobierno panista de Francisco Ramírez Acuña, elegido a finales de 2000 en un proceso muy cuestionado y que ganó por una pequeña diferencia, representó una regresión autoritaria (Aziz, 2003). Este gobernador fue acusado de antidemocrático ${ }^{1}$, prepotente, alejado de los reclamos de los organismos ciudadanos y de no haberse destacado por atender con eficacia los principales problemas del estado. También se le ha imputado ser un personaje sin carisma, nada popular, deslumbrado por el poder, el dinero y el estilo de vida de los acaudalados. Durante su gestión la entidad sufrió importantes rezagos².

\footnotetext{
1 "Una incursión antropológica en algunos de los grupos del mismo partido que el del gobernante deja la constancia de un disgusto celosamente guardado hacia la gestión estatal, y que cundió el miedo de sufrir las represalias de un poder ejercido sin miramientos en beneficio de caprichos personales. La norma dejó de ser la regla de certidumbre, y se pasó al favor o al castigo que dependen de la pura arbitrariedad. La generación del miedo por parte de la autoridad no es ciertamente una muestra de una cultura política democrática [...]. Y esto se manifestó desde el principio de su gestión. En una encuesta de Público Berumen publicada el 31 de enero de 2002 se confirmaba que $41.5 \%$ de los que votaron por Ramírez Acuña en 2000 estaban arrepentidos de su voto" (Alonso, 2002).

${ }^{2}$ Ejemplo de ello es que, a pesar de que Jalisco es uno de los estados de la República que ocupan los primeros sitios por el número de sus pobladores, su nivel de competitividad ha bajado al sitio 17 , como se comprueba en el estudio Doping Business 2007, del Banco Mundial, $<$ www. bancomundial.org $>$. El 22 de noviembre de 2006 el Instituto
}

Abundaron también las denuncias de corrupción y del mal uso de recursos públicos. Se le criticaron sus frecuentes viajes al extranjero pagados con dinero de los contribuyentes, de los cuales no se han rendido cuentas convincentes (Martín y Regalado, 2006). La prensa local ha confirmado el malestar por el retraso de obras públicas, que, además, no están bien construidas 3 . El gobierno del estado ha desdeñado la transparencia. Su gestión ha sido señalada por auspiciar la tortura 4 . En octubre de 2006 una publicación gubernamental con tiraje de cien mil ejemplares resaltó en un cintillo que "Los derechos humanos son para todos, menos para los delincuentes" 5 . Más allá de la violación que esto implica de los tratados internacionales de derechos humanos, la queja versaba sobre el hecho de que los torturadores convertían a inocentes en delincuentes ${ }^{6}$. Una fiesta masiva de jóvenes fue brutal-

Mexicano para la Competitividad entregó los premios de competitividad estatal a nueve estados de la República mexicana. Jalisco no estuvo entre ellos. De acuerdo con el índice delictivo del fuero federal integrado por la Procuraduría General de la República, al terminar 2006 Jalisco ocupaba el segundo lugar de entidades con mayor índice delictivo, <www.pgr.gob.mx>. De acuerdo con un estudio del Consejo Nacional de Evaluación de la Política de Desarrollo Social publicado en noviembre de 2006, en los índices de marginación respecto al porcentaje de población de 15 años y más con educación básica incompleta, Jalisco se ubica en el lugar 15 con $46.9 \%$; y en el porcentaje de población sin derecho-habiencia a servicios de salud está en el sitio 16 con 44.8\%. En un apretado balance de la gestión del gobierno de Ramírez Acuña se señala que había prometido crear 70 mil empleos anuales, pero no llegó a 28 mil. Un déficit de 270 mil empleos obligó a que anualmente 58 mil jaliscienses emigraran a Estados Unidos en busca de trabajo. Otro renglón deficitario es el relativo a la distribución del ingreso. Jalisco sí está en los primeros lugares en el país, pero en desigualdad. Pese a que se encuentra en el cuarto lugar por su contribución al Producto Interno Bruto (PIB), a la hora de su reparto per capita desciende al sitio 14 (Martín, 2006).

${ }^{3}$ Estos datos se pueden encontrar en los periódicos Público y Mural. ${ }^{4}$ El 3 de noviembre de 2006 la Comisión Estatal de Derechos Humanos de Jalisco insistió en que, ante las reiteradas denuncias de tortura, responsabilidad del gobierno jalisciense, no se podía tapar el sol con un dedo y que era urgente que la autoridad reconociera, primero, la existencia de la tortura y, segundo, que llevara a cabo acciones necesarias para resolver la magnitud de este grave problema (Público, 4 de noviembre de 2006). Sándor Márai anota que la crueldad es un opio que no puede abandonar a quienes la han probado; resulta necesario aumentar la dosis para obtener la misma satisfacción (Márai, 2006).

${ }^{5}$ Gaceta del Gobierno de Jalisco, octubre de 2006, pp. 8 y 9.

${ }^{6}$ El editorial del periódico El Universal del 9 de noviembre de 2006, al recordar los atropellos a activistas en Guadalajara, apuntó: "En un país en donde los delincuentes actúan con impunidad, los torturadores se ceban generalmente en personas inocentes, para arrancarles confesiones imposibles, extorsionarlos o aparentar resolver ilícitos". 


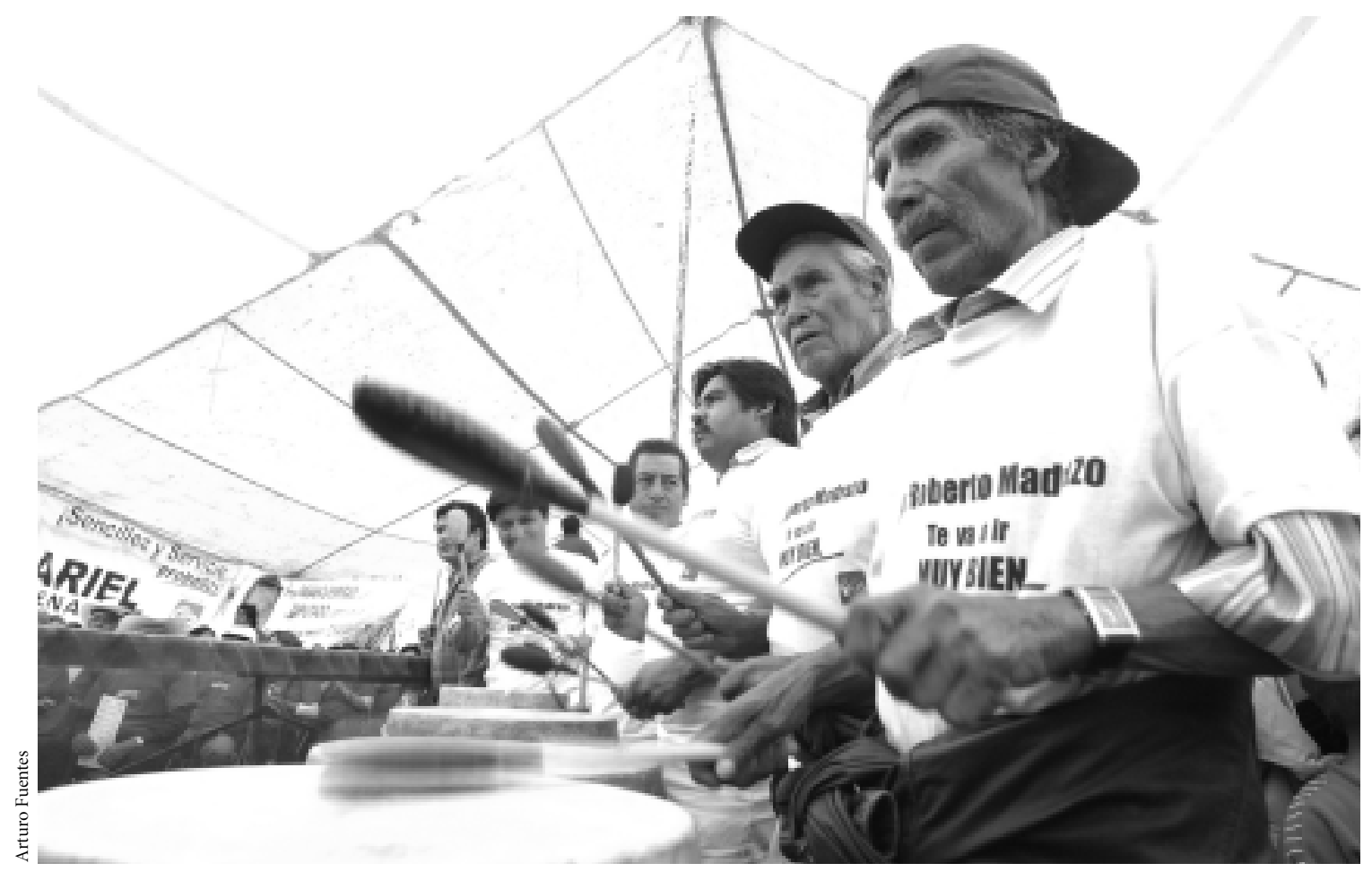

El PRI en campaña, proceso electoral de 2006.

mente reprimida. Posteriormente, el gobierno jalisciense fue acusado nacional e internacionalmente por haber realizado detenciones ilegales, vejado a los apresados y aplicado prácticas de tortura ${ }^{7}$. Un día después de este he-

\footnotetext{
${ }^{7}$ Se puede consultar el informe especial de la Comisión Nacional de Derechos Humanos (CNDH) relativo a los hechos de violencia en la ciudad de Guadalajara, ocurridos el 28 de mayo de 2004 con motivo de la celebración de la III Cumbre de América Latina, el Caribe y la Unión Europea. Ante el Comité contra la Tortura de la Organización de las Naciones Unidas (ONU), el 7 de noviembre de 2006 la CNDH denunció que la tortura era una práctica frecuente en las corporaciones policiacas mexicanas por la tolerancia de los gobiernos federales y estatales. Puso como ejemplo el caso de los altermundistas torturados en Guadalajara el 28 de mayo de 2004. El 8 de noviembre, el Comité contra la Tortura de la ONU cuestionó la parálisis de las autoridades mexicanas para resolver los asesinatos de mujeres en Ciudad Juárez, la represión en Guadalajara en 2004 y la de Atenco en 2006. El representante en México de la Oficina del Alto Comisionado de Naciones Unidas para los Derechos Humanos presentó, el 13 de noviembre de 2006, un balance del comportamiento del gobierno de Vicente Fox ante los derechos humanos. Señaló que durante la administración foxista fueron persistentes las violaciones a los derechos humanos, sobre todo en las temáticas de migración, discriminación hacia los pueblos indígenas,
}

cho, el gobernador organizó un acto masivo para "destapar" como precandidato a la presidencia de la República al entonces secretario de Energía, Felipe Calderón. Se interpretó que la represión había sido para demostrar que el gobernador tenía mano dura para tratar a los manifestan-

violencia contra las mujeres, precarización del trabajo, etc. Destacó el caso de Guadalajara en 2004, y los de Atenco y Oaxaca en 2006. Se quejó de la impunidad, pues no se había castigado a los responsables de las violaciones a los derechos humanos en esos acontecimientos, $<$ www.un.org.mx $>$. El 11 de febrero de 2007 Amnistía Internacional indicó que, en materia de derechos humanos, en México había impunidad; entre los ejemplos que presentó se encontraba el caso del 28 de mayo de 2004 en Guadalajara (<www.amnistia.org.mx>). El 23 de noviembre de 2006, ante la petición de licencia del gobernador Ramírez Acuña por pasar a formar parte del gabinete de Felipe Calderón, organismos civiles hicieron una evaluación de su gobierno. Lo reprobaron en derechos humanos y hubo fuertes críticas al deterioro ambiental (Público y Mural, 24 de noviembre de 2006). El periodista Diego Petersen recordó algunos rasgos de Ramírez Acuña: "No le gusta la sociedad civil organizada y con el mismo desprecio lo ven las ONG [...]. La transparencia no es lo suyo porque le estorba para gobernar" ("Ramírez Acuña ante el tablero", Público, 25 de noviembre de 
tes altermundistas y que aspiraba a ser secretario de Gobernación (Alonso, 2006a). Desde entonces, Ramírez Acuña se metió de lleno a apoyar, primero, la precampaña de Calderón, y luego su campaña por la presidencia del país. En octubre de 2005 la periodista Ivabelle Arroyo publicó un artículo en el que argumentaba que el gobernador había incurrido en una acción delictiva. Escribió:

Ramírez Acuña ha olvidado no sólo al estado que pretendía gobernar, sino los más elementales principios del servicio público [...]. Usó un avión privado para viajar a los suelos yucatecos, campechanos y veracruzanos, sedes de la campaña calderonista [...]. O el avión fue rentado con cargo al erario o con cargo a un amigo. En el primer caso, Ramírez Acuña cometió un delito que se llama peculado, cuyo castigo es la cárcel [...]. Dijo el gobernador que el dinero era de un empresario [...]. El flamante mandatario viajero con aspiraciones de Secretario federal, recibió una dádiva de 164 mil pesos [...]. La ley es clarísima: si recibe un regalo superior a 10 veces el salario mínimo del D. F., el gobernador está cometiendo cohecho y la pena es también [...] de prisión [...]. Antes, a todo esto se le llamaba corrupción (Arroyo, 2005).

De esta participación en la campaña de Calderón, que fue un episodio entre muchos más, nada se aclaró. Ramírez Acuña planeó el incremento de la obra pública para utilizarla electoralmente. Se propuso incidir tanto en los comicios presidenciales como en los locales.

\section{UN ORGANISMO ELECTORAL PARTIDIZADO Y CUESTIONADO}

Aunque el Consejo Electoral del Estado de Jalisco había propuesto un cambio integral a la legislación electoral, el Congreso optó por modificaciones menores. En mayo de 2005 cambió el nombre de Consejo a Instituto, y en lugar de que los consejeros duraran en su cargo cuatro años, lo subió a cinco. Planteó que los partidos debían obtener 3.5\% de la votación para participar en el reparto de diputados de representación proporcional, y no se hizo bien el ajuste, pues en la Constitución ese porcentaje se refería a la votación válida ${ }^{8}$, mientras que en la ley

2006).

${ }^{8}$ La fracción segunda del artículo 20 constitucional dice: "Todo parti- se planteaba que correspondía a la votación total. Para el nombramiento del nuevo consejo se siguieron las cuotas partidistas, intervino el gobernador para que se incluyeran a operadores fieles y se construyó un organismo partidizado, autónomo sólo de nombre. Este nuevo organismo ajustó la distritación electoral. Fueron cambiados de los anteriores distritos 26 municipios y 144 secciones electorales para que hubiera parecido con la distritación federal, aunque se mantuvieron 20 distritos locales frente a los 19 federales. Las divisiones básicas - las seccionesalcanzaron el número de 3326 . Algunos de los integrantes del organismo electoral estaban vinculados con quien había sido el candidato prísta en 1995, con influencia en la organización de las campañas del Partido Revolucionario Institucional (PRI), pero la coyuntura no les fue favorable ${ }^{9}$

\section{INTERMINABLESY ONEROSAS PRECAMPAÑAS}

Los partidos nunca quisieron regular las precampañas, con lo que dejaron amplios márgenes de maniobra en cuanto a recursos (de los cuales no darían cuentas ni del origen ni de su destino) y para alargar de hecho los tiempos de propaganda electoral. El Partido Acción Nacional (PAN) se apresuró a contar con sus candidatos para el gobierno y para los principales ayuntamientos a finales de 2005. Se disputaron las candidaturas locales el grupo cercano al gobernador y el grupo de quien había sido presidente municipal de Guadalajara de 2001 a 2004, Fernando Garza. El ex secretario de Salud, Alfonso Petersen, ganó la postulación por el ayuntamiento de Guadalajara. En Zapopan, el ex secretario de Educación, Guillermo Martínez Mora, perdió ante un candidato local, Juan Sánchez Aldana. En la disputa por la candidatura para el

do político que alcance cuando menos 3.5\% de la votación, sin considerar para tal efecto los votos nulos y los de candidatos no registrados, tendrá derecho a participar en el procedimiento de asignación de diputados según el principio de representación proporcional".

${ }_{9}^{9}$ Entrevista con Alonso Ulloa, miembro del equipo de la campaña de Emilio González, candidato del PAN a gobernador, 22 de septiembre de 2006. 
gobierno de Jalisco triunfó Emilio González, quien era alcalde de Guadalajara. Fernando Garza denunció que se había dado una elección de Estado y no quería reconocer los resultados. Finalmente se impuso la disciplina y el PAN enfrentó las elecciones unido. Para reforzar su campaña lanzó como candidato para el Senado al ex gobernador Alberto Cárdenas, quien ha mantenido una buena imagen en la entidad.

Las precampañas en el PRI fueron más prolongadas. Una gran variedad de grupos peleaba por las candidaturas en todos los niveles. Sin un liderazgo unificador, el PRI jalisciense enfrentó las elecciones disgregado y con grandes rupturas internas. A principios de enero aspiraban a ser candidatos por el gobierno del estado el presidente municipal de Zapopan, Arturo Zamora; el líder de la bancada de los diputados priístas, Ramiro Hernández; una alta funcionaria del PRI a nivel nacional, María Esther Sherman, y el dirigente del PRI jalisciense, Javier Guízar. Por medio de una encuesta habían dejado fuera a otros cuatro aspirantes: Javier Santillán, Humberto Álvarez, Julián Orozco y Francisco Morales, quienes, como los demás, llevaban ya mucho tiempo con costosas campañas mediáticas. El senador Raymundo Gómez Flores, aunque gastó mucho promocionándose, cuando calculó que no tenía el respaldo necesario para ganar la contienda interna prefirió hacerse a un lado.

El periódico Público contrató a la empresa Contacto Media Research Service para que hiciera un cálculo de lo que los precandidatos a la gubernatura de Jalisco habían destinado para pagar spots de radio y televisión hasta la primera semana de enero de 2006. A Emilio González le atribuían un gasto de 19 millones; a Ramiro Hernández, 11.4 millones; a Raymundo Gómez Flores, 11.3 millones; a Arturo Zamora, 7.8 millones; a Javier Guízar, 2.7 millones; a Fernando Garza, 1.5 millones. Los demás no superaban el millón cada uno. A esto habría que sumar los recursos que los candidatos a las alcaldías destinaron a sus respectivas campañas. Por ejemplo, en el PRI peleaban por la candidatura por Guadalajara un médico que había estado al frente de los hospitales civiles, Leobardo Alcalá, y un diputado local, Aristóteles Sandoval. El primero llevaba gastado en medios electrónicos 2.5 millones, y el segundo, 1.5 millones. Esto no tomaba en cuen- ta otras erogaciones, como lo destinado a otros medios de difusión, pago de giras y los costos del personal de campaña. Era ostensible el despliegue de muchas camionetas nuevas en la precampaña de Ramiro Hernández, que provenían del gobierno del Estado de México.

El llamado Grupo Universidad de Guadalajara, pese a que tenía el control del Partido de la Revolución Democrática (PRD) local, ostensiblemente apoyaba las candidaturas príístas de Zamora para la gubernatura, y de Alcalá para la presidencia municipal de Guadalajara. Zamora recibió también el respaldo de los principales sindicatos de la entidad. Se corría el rumor de que el gobernador Ramírez Acuña tenía buenos tratos con él y que podría hasta apoyarlo ${ }^{10}$. Sherman y Guízar se salieron de la contienda argumentando insuficiencia de recursos. Zamora ganó la candidatura, pero Hernández se quejó de relleno de urnas y de coacción del voto. En el PRI querían que las decisiones sobre las demás candidaturas se tomaran lo más cercano al registro oficial de candidaturas, no sólo para tener más tiempo de campaña, sino para evitar que importantes cuadros se fueran a otros partidos. El PRD le ofreció su candidatura a Ramiro Hernández, quien, pese a su descontento, no aceptó y prefirió hacer arreglos internos, los cuales, al margen de la normatividad acordada, le permitieron encabezar la primera fórmula para el Senado, con lo cual, aunque perdiera, tenía asegurada la curul.

El PRD designó, desde la dirección nacional, como su principal candidato a Enrique Ibarra, un ex prísta, quien antes había impulsado la precampaña de Zamora. Debido a que el Partido Verde exigía muchas posiciones, el PRI no quiso ir en alianza con este partido en Jalisco. Para la gubernatura, el Partido Verde postuló a Adalberto Velas$\mathrm{co}$, quien posteriormente renunció para colocarse en una candidatura a una diputación. La alianza nacional entre el PRD, el Partido del Trabajo (PT) y Convergencia tampoco se refrendó a nivel local. Se presentaron unidos los

\footnotetext{
${ }^{10}$ Desde antes de que se iniciaran formalmente las campañas, Ramírez Acuña "metió las manos a fondo en el proceso interno del PRI. Específicamente maniobró para que ese partido postulara a su amigo y ex asesor Arturo Zamora Jiménez [...]. Muchos militantes panistas y prístas no tenían claro si el gobernador apoyaba más a Zamora que al candidato blanquiazul" (Cobián, 2006: 29).
} 


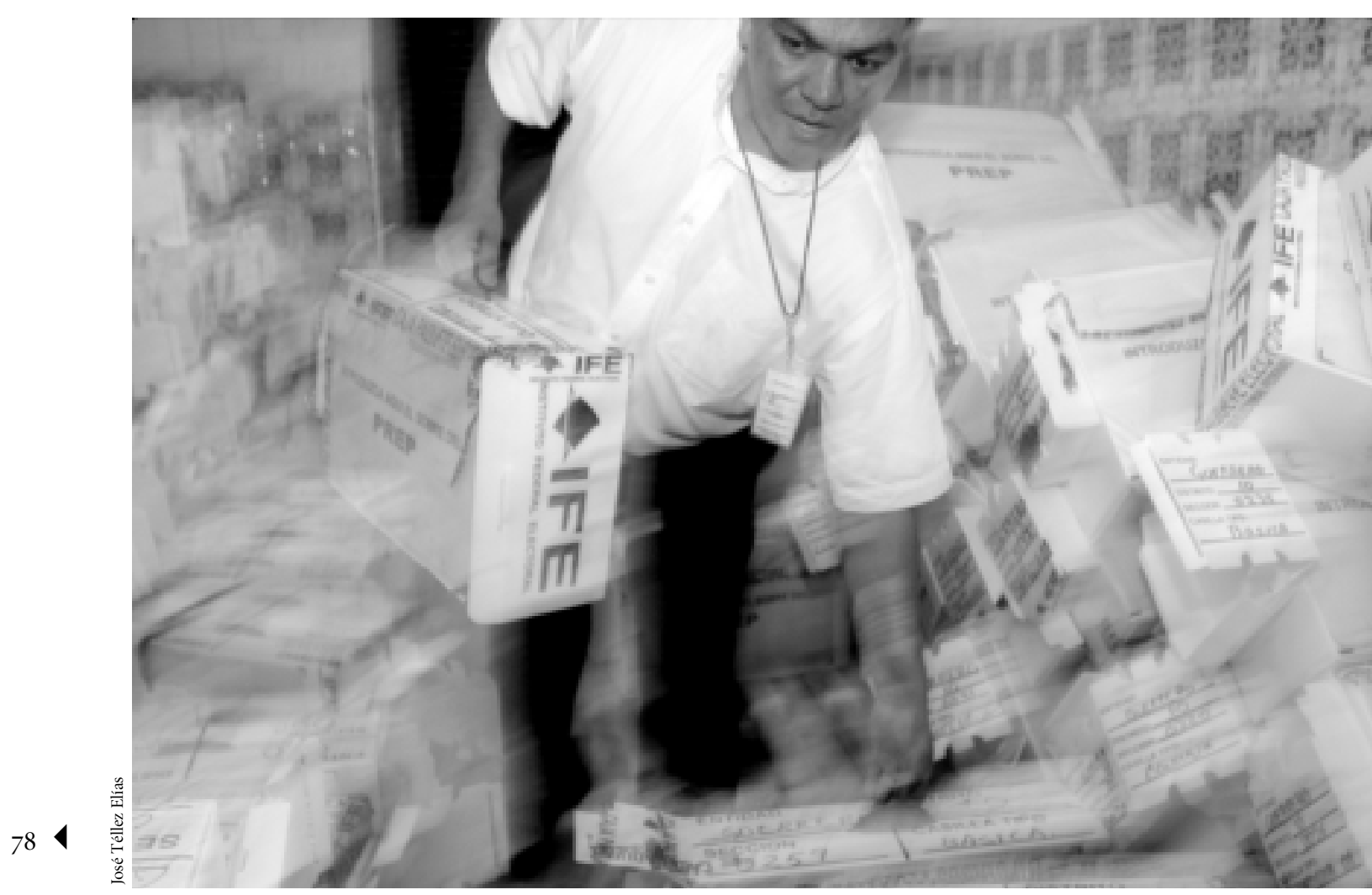

Proceso electoral de 2006, Acapulco, Guerrero.

dos primeros. Convergencia postuló a Antonio Jaime Reynoso para aspirar al gobierno del estado. El partido Alternativa puso a la joven Olivia Ornelas, y el partido de los maestros, Nueva Alianza, lanzó al ex priísta Fernando Espinoza.

El Instituto Electoral del Estado de Jalisco ordenó una tregua del 26 de enero hasta el primero de abril, la cual no impedía las precampañas de los puestos que no estaban definidos, lo que le permitía al PRI seguir en campaña. El PAN denunció inequidad. No obstante, los candidatos a la gubernatura encontraban medios para sus actividades proselitistas, como fueron la presencia de sus respectivos candidatos presidenciales en la entidad. En una de estas visitas, Madrazo se quejó de que el gobierno panista pretendía dar un golpe mediático en contra de Zamora.

La tregua hubiera implicado un respiro en febrero y marzo, pero las campañas presidenciales y las pugnas in- ternas en el PRI siguieron marcando una larga contienda interna que mediáticamente se hacía externa. Otro problema que repercutió en el ánimo de los priístas fue el dinero que tenían que poner los candidatos del PRI para poder entrar en el juego de las designaciones internas. El PRI estableció una estructura de finanzas paralela a su Secretaría de Finanzas. Trascendió que Zamora y Hernández habían tenido que pagar 6.4 millones de pesos. Para aspirar a competir por diputaciones y alcaldías, además de una cuota de inscripción, debían contribuir para el costo de las encuestas y de cada proceso interno ${ }^{11}$. Hubo quejas de que las encuestas no fueron enseñadas a los perdedores y de que los procesos no habían sido transparentes. El contralor interno del PRI denunció que nada se

\footnotetext{
${ }^{11}$ Mural y Público, 2 de marzo de 2006.
} 
sabía de alrededor de 80 millones de pesos recaudados entre los aspirantes a alguno de los puestos electorales ${ }^{12}$. Hubo acusaciones de que los procesos internos eran imposiciones disfrazadas y de que las listas tenían que pasar por la aprobación de Zamora. El descontento abrió la puerta para que muchos impulsaran candidaturas de otros partidos. En febrero, cientos de prístas de Tlajomulco anunciaron que no apoyarían las campañas de su partido. También varios diputados, alcaldes y regidores priístas siguieron la diáspora. Cuadros importantes del PRI, así como líderes sindicales pasaron ostensiblemente a propagandizar la candidatura del PAN. La dirigencia príista se quejó de que en sus filas hubo traidores que se fueron al PAN por dinero. En 80 municipios hubo candidatos priístas en otras planillas. El PAN buscó alianzas con priístas descontentos y con militantes del Partido Verde. El gobernador distribuyó con tinte electoral recursos de excedentes petroleros para municipios.

Hubo 8293 candidatos para los puestos municipales. El PAN y el PRI participaron en los 125 municipios. La alianza PRD-PT se presentó en 119. El Partido Verde consiguió proponer planillas en 63; el Partido Nueva Alianza en 57, Convergencia en 40 y Alternativa Socialdemócrata en 14. Esto mostró la influencia de cada partido en la entidad.

\section{EN LAS CAMPAÑAS IMPERA LA GUERRA SUCIA}

Emilio González y Arturo Zamora aprovecharon sus gestiones como presidentes municipales de Guadalajara y de Zapopan, respectivamente, para impulsar sus propias campañas. No obstante, había algunas diferencias. Zamora había establecido fuertes nexos con empresarios y con los medios de comunicación, lo cual le redituó una buena imagen pública, pues los generadores de opinión habían apostado por él. Emilio González no supo tejer ese tipo de redes e iniciaba en desventaja. Comenzó su campaña con varios puntos debajo de su contrincante.

12 Proceso, 30 de julio de 2006.
No obstante, fue acortando la distancia a lo largo de su campaña.

El candidato priísta a la gubernatura hizo 81 promesas; el panista, 74. Ninguno dijo cómo se cumplirían ${ }^{13}$. Las campañas por el gobierno de la entidad fueron muy ríspidas. El organismo electoral exhortó a evitar las campañas de desprestigio, pero nadie le hizo caso. Tampoco fueron atendidos los llamados de organismos cívicos para que se hicieran campañas de altura. A finales de marzo Zamora tuvo que aceptar que había declarado menos bienes de los que tenía. El PAN denunció que la Secretaría General de la Universidad de Guadalajara utilizaba recursos públicos a favor del candidato prí́sta. Hubo un enfrentamiento entre el PAN y la cúpula universitaria. Utilizando a los mismos actores en varios spots, tanto el PAN como el PRI se acusaron de mentirosos. Alcaldes prístas dieron despensas a cambio de votos. El PAN fue denunciado por utilizar los programas sociales en provecho de sus candidatos. Algunos de ellos fueron exhibidos entregando tinacos y varillas, sacos de cemento y láminas a cambio de apoyo electoral ${ }^{14}$. El PRI y el PRD se quejaron de que el PAN había rebasado los topes de campaña. Mientras tanto, el PAN aseguraba que el candidato priísta tenía nexos con el narcotráfico. A finales de mayo, el presidente nacional del PAN entregó un expediente en el que el candidato príista se encontraba implicado en un fraude al Instituto Mexicano del Seguro Social (IMSS). De inmediato, la Procuraduría General de la República (PGR) llamó a ese candidato a declarar como testigo. Durante la última semana de la campaña el candidato de Nueva Alianza sacó un spot de radio en el que invitaba a no votar por Zamora por sus nexos con narcotraficantes. El día que terminaban las campañas se dio a conocer profusamente que la PGR había asegurado varias casas del candidato priísta debido a la investigación del fraude al IMSS. Poco después, la PGR comunicó que se había cancelado el aseguramiento de las casas de Zamora, porque éste había presentado documentos para avalar la legalidad de sus propiedades, pero el daño ya estaba hecho.

\footnotetext{
${ }^{13}$ Mural, 28 de julio de 2006.

${ }^{14}$ El periódico Público difundió el 11 de septiembre de 2006 que en el año electoral el gobierno jalisciense había duplicado los regalos de cemento, que beneficiaron a 9668 familias.
} 
Prevaleció la campaña del miedo y el odio instigada por el panismo nacional en contra del candidato presidencial Andrés Manuel López Obrador, apoyada en los medios electrónicos de comunicación, en correos por Internet y en llamadas pagadas de telefonía celular. Cundieron las patrañas de que, si ganaba ese candidato, la gente perdería sus casas y que los que poco tenían se quedarían sin lo que hubieran comprado a crédito. Organismos de la sociedad civil se quejaron de que sobre las propuestas había prevalecido la guerra de lodo. En las parroquias de la Arquidiócesis de Guadalajara se dieron talleres "para decidir bien". Hubo quejas de que en ellos se impulsaba la opción panista.

\section{ENCUESTAS, COBERTURA MEDIÁTICA Y GASTOS PARTIDISTAS}

La encuesta de consulta Mitofsky de principios de año daba una ventaja a Zamora de siete puntos. En febrero, la encuesta del periódico El Informador apuntaba una ventaja del candidato prísta de 5.2 puntos. En las encuestas publicadas por el periódico Mural, Zamora tenía ventaja en las correspondientes a febrero y marzo. En esta última llegó a colocarse 16 puntos por arriba. No obstante, en las encuestas de mayo y junio hubo un vuelco y el candidato panista superó por tres y dos puntos respectivamente a su contrincante. Las encuestas a cargo de María de las Heras siempre aseguraron que Zamora se encontraba arriba: en marzo con seis puntos, en mayo con tres, y en junio con cinco. En opinión del representante del PRI ante el organismo electoral, los que hacían encuestas habían engañado a Zamora haciéndole creer que tenía una fuerte ventaja ${ }^{15}$.

A mediados de junio se difundió un seguimiento de la cobertura informativa realizado por la empresa Orbit Media, contratada por el organismo electoral, según la cual el PRI encabezaba la intención electoral con 39\% del total de la información publicada, seguido por el PAN con $32.8 \%$; en la televisión, el PRI tenía 32.5\% y el PAN 28.5\%;

${ }^{15}$ Entrevista con Jesús Reynoso, 22 de octubre de 2006. en radio, el PRI seguía a la cabeza con 41.6\%, mientras que el PAN se quedaba con $32 \%$. Finalmente, en periódicos y revistas, el PRI llegaba a $41.6 \%$ y el PAN se mantenía en $32.9 \%$. Las cifras para los demás partidos estaban muy lejos de los dos principales contendientes. El tope fijado por el organismo electoral para la campaña de gobernador fue de 26 millones. En sus reportes, el PRI adujo que había gastado 24.9 millones. Por su parte, el PAN aducía que esa campaña le había costado 22.7 millones ${ }^{16}$. La prensa local dijo que esos reportes no eran creíbles ${ }^{17}$. Según los monitoreos de Orbit Media, sólo teniendo en cuenta la propaganda en medios de comunicación y en anuncios espectaculares, la campaña panista para gobernador había llegado a la cantidad de 42.2 millones, mientras que la del PRI alcanzaba los 31.2 millones. De acuerdo con esto, ambos partidos habían superado los topes de sus campañas de gobernador. Los panistas argüían que ellos se habían movido de acuerdo con los márgenes que daba la ley y que habían conseguido negociaciones de tres anuncios a precio de uno. No obstante, una campaña para gobernador implica vehículos, gasolinas, hoteles, comidas, otra clase de promocionales, pagos de teléfonos, de renta de la casa de campaña y del equipo que apoya la campaña, todo lo cual aumenta los montos erogados. Un diputado prísta reconoció que el costo de una campaña para gobernador costaba más de cien millones de pesos $^{18}$. Esto obliga a tener una contabilidad oficial, ajustada a los topes legales, y otra real, que se oculta.

Antes de las elecciones se prefiguraron dos tendencias que indicaban que habría alternancia en la presidencia federal y en el gobierno jalisciense. Ambos gobiernos utilizaron todo lo que estaba a su alcance (legal e ilegalmente) para impedirlo. Hubo un gasto desmedido, sobre todo en medios de comunicación, para detener a los contrincantes e impulsar a los candidatos del PAN. Esto determinó los resultados.

\footnotetext{
${ }^{16}$ Informes financieros entregados al Instituto Electoral del Estado de Jalisco, <www.ieej.org.mx $>$.

17 Público, 24 de agosto de 2006.

18 Público, 20 de febrero de 2006.
} 


\section{PROBLEMAS CON REPRESENTANTES DE PARTIDOS EN LAS CASILLASY CON FUNCIONARIOS DE LAS MISMAS}

En Jalisco se instalaron 8020 casillas. De acuerdo con la información oficial del organismo electoral federal, el PAN acreditó 6995 representantes (86.5\%); Alianza por México (PRI y PVEM), 7861 (97.2\%); la Coalición por el Bien de Todos, 7461 (92.2\%), y Nueva Alianza, 6509 (80.4\%). No obstante, la presencia real fue de 6312 para el PAN (78.7\%); 6746 para la Alianza por México (84.1\%); 4417 para la Coalición por el Bien de Todos (55.1\%), y 2926 para Nueva Alianza (36.5\%). Su distribución en los distritos también tuvo grandes variaciones, como se puede apreciar en el cuadro 1.
En unas elecciones presidenciales muy competidas ninguno de los partidos y coaliciones pudo tener representación en todas las casillas. Pese a la alianza de facto que estableció el Partido Nueva Alianza con el PAN en la elección presidencial, entre los dos no alcanzaron a cubrir todas las casillas en el distrito IX tapatío. Por otra parte, el distrito VIII, también de Guadalajara, tuvo representantes priístas y perredistas en menos de la mitad de las casillas. En el caso de la Coalición por el Bien de Todos surgieron problemas de falta de coordinación entre los partidos de esa coalición y las redes ciudadanas. Además, se encontraron con otros obstáculos. Un dirigente perredista se quejó de que en 30\% de las casillas los representantes registrados por la Coalición no habían sido reconocidos, pues a pesar de que presentaban su acreditación, no se encon-

Cuadro 1. Porcentaje de representantes partidarios por distritos

\begin{tabular}{|c|c|c|c|c|}
\hline Distritos & PAN & Alianza por México & Por el Bien de Todos & Nueva Alianza \\
\hline I. Tequila & 85.2 & 83.9 & 77 & 32 \\
\hline II. Lagos de Moreno & 90.7 & 94.5 & 64.8 & 34.4 \\
\hline III. Tepatitlán & 88.3 & 84.4 & 52.6 & 29.6 \\
\hline IV. Zapopan & 60.8 & 79.5 & 41.1 & 46.7 \\
\hline V. Puerto Vallarta & 91.3 & 91.3 & 33.5 & 37.4 \\
\hline VI. Zapopan & 68.6 & 94.1 & 52.1 & 47.2 \\
\hline VII. Tonalá & 77.6 & 98.2 & 85.8 & 36.9 \\
\hline VIII. Guadalajara & 87.5 & 47 & 49.5 & 62.2 \\
\hline IX. Guadalajara & 89.2 & 99.5 & 90.4 & 5.9 \\
\hline X. Zapopan & 66.2 & 92.6 & 46.3 & 60.1 \\
\hline XI. Guadalajara & 79.1 & 51.3 & 57.2 & 27.1 \\
\hline XII. Tlajomulco & 71 & 89.8 & 58 & 31.8 \\
\hline XIII. Guadalajara & 46.4 & 84.6 & 18.4 & 29.9 \\
\hline XIV. Guadalajara & 68.9 & 52.6 & 16.5 & 25 \\
\hline XV. La Barca & 83.3 & 94.3 & 60.3 & 24.8 \\
\hline XVI. Tlaquepaque & 71.3 & 93.3 & 22.8 & 34.3 \\
\hline XVII. Jocotepec & 99.9 & 86.7 & 77.4 & 31.6 \\
\hline XVIII. Autlán & 90.8 & 94.3 & 80.9 & 63 \\
\hline XIX. Ciudad Guzmán & 82.7 & 93.8 & 66.5 & 31 \\
\hline
\end{tabular}

FUENTE: Instituto Federal Electoral (IFE). 
traban en las listas de las casillas ${ }^{19}$. El regidor del Partido Verde en Guadalajara participó su experiencia en este campo. La lista de 150 personas propuestas para ser representantes fue perdida en el organismo electoral local y a otros los ubicaron en sitios lejanos a las casillas en las que habían aceptado estar. Cuando protestó, le respondieron que eso había sucedido por un problema del sistema de cómputo ${ }^{20}$.

El ex consejero ciudadano a nivel federal, Miguel Ángel Granados Chapa, escribió:

A partir de la Dirección de Organización Electoral del IFE, cuyo titular es un antiguo cuadro sindical del SNTE [Sindicato Nacional de Trabajadores de la Educación Nacional] [... el magisterio dirigido por Gordillo tuvo varios papeles eminentes, como la capacitación y suplencia de funcionarios electorales. Es significativo que Nueva Alianza, un partido pequeño, de nueva creación, que se jugaba su permanencia, fuera el único representado en cierto número de casillas donde supo, quizá por información confidencial, que ninguno de los partidos había registrado representantes ${ }^{21}$.

En un encuentro internacional de ciencias sociales, Clara Jusidman dijo:

La sospecha de que el SNTE y Elba Esther Gordillo lograron incorporar a miles de maestros como funcionarios de casilla mediante acuerdos con capacitadores y funcionarios del IFE, vinculados a ese sindicato, sustituyendo a ciudadanos originalmente insaculados, es un asunto insuficientemente aclarado por el IFE (Jusidman, 2006)22.

\footnotetext{
${ }^{19}$ Entrevista con Claudio Palacios, 19 de octubre de 2006.

${ }^{20}$ Entrevista con Martín Márquez, $1^{\circ}$ de octubre de 2006.

${ }^{21}$ Miguel Ángel Granados Chapa, "El SNTE gobierna”, Reforma, 18 de octubre de 2006

22 El periódico Reforma dio a conocer el 21 y 22 de enero de 2007 que, al interior del SNTE, Elba Esther Gordillo tenía una estructura pagada para operar en las elecciones constitucionales. Al hacerse público este hecho, legisladores del PRI y del PRD condenaron el hecho y demandaron al IFE emitir un juicio sobre esa estructura. Miguel Ángel Granados Chapa, a propósito del pago de favores de Calderón a Elba Esther Gordillo, recalcó el 11 de febrero de 2007 que el partido de Gordillo y el sindicato magisterial que ella controla "pusieron votos y trampas al servicio de Calderón [...]. En la zona oscura del proceso, cuadros magisteriales, especialmente entrenados al efecto, y en combinación con funcionarios del IFE (el director de Organización de ese instituto se formó en la tradición de las argucias electorales practicadas por profesores), proveyeron otro insumo necesario: la manipulación de los votos en las urnas y las actas" (Miguel Ángel Granados Chapa, "La Presidenta y el Presidente", Reforma, 11 de febrero de 2007).
}

\section{LAS ELECCIONES PRESIDENCIALES}

Pese a que se constituyó un ambiente que distorsionó el ánimo de los electores, el examen de los números permite percibir algunas tendencias que hay que tener en cuenta. En las elecciones presidenciales de 1994 a 2006, en números absolutos, el PAN aumentó su votación presidencial en Jalisco. En cambio, el PRI ha sufrido importantes pérdidas tanto en números absolutos como relativos. El voto de la izquierda, que tuvo un ligero retroceso en el año 2000, experimentó un alto crecimiento en 2006, pues se triplicó. El más de medio millón de votos obtenidos implicó que uno de cada cinco votantes lo había hecho por esa opción. No obstante, en términos relativos, López Obrador obtuvo 4.2 puntos menos que lo logrado en Jalisco por Cuauhtémoc Cárdenas en 1988. Aunque ha crecido el número de ciudadanos que acuden a las urnas, si se toma en cuenta el monto de los ciudadanos inscritos en el padrón electoral en 2006 hay un importante descenso en la participación electoral, pues la abstención en dicho año fue 21.7 puntos mayor que en 1994 (véase cuadro 2, p. 85). No obstante, Jalisco ocupó el octavo sitio entre los estados con mayor participación ciudadana ${ }^{23}$ y fue el segundo estado en el que el PAN obtuvo mayor número de votos, sólo superado por el Estado de México. El candidato presidencial panista estuvo arriba en todos los distritos jaliscienses. El PRI quedó en un lejano segundo lugar. En el distrito del norte, el PAN superó al PRI por diez puntos. Ventajas de entre 13 y 19 puntos las logró en los distritos del sur del estado, en la costa y en los distritos metropolitanos de Tlajomulco y Tonalá. Distancias de entre 23 y 30 puntos sobre el PRI las consiguió en el distrito ribereño de la Barca y en los distritos metropolitanos de Zapopan y Guadalajara. Ventajas de entre 33 y 38.5 puntos las tuvo en distritos de Zapopan, Guadalajara y en los alteños de Lagos y Tepatitlán. Finalmente, en un distrito zapopano, la distancia panista respecto de la votación prísta fue de 40.7; en

\footnotetext{
${ }^{23}$ El conteo del Instituto Nacional de Estadística, Geografía e Informática (INEGI) de 2005 arrojaba que había alrededor de 13\% menos de personas en capacidad de votar que los enlistados en el registro electoral. Esto implicaría que el porcentaje de los que votaron fue más
} 
Cuadro 2. Elecciones presidenciales en Jalisco

\begin{tabular}{l|r|r|r}
\hline & 1994 & 2000 & \multicolumn{1}{|c}{ 2006 (Resolución del Tribunal) } \\
\hline PAN & $1008234(41.9 \%)$ & $1392535(53 \%$ con PV) & $1426237(50.45 \%)$ \\
\hline PRI & $1050815(43.6 \%)$ & $941962(35.9 \%)$ & $698379(24.7 \%$ con PV) \\
\hline PRD & $166226(6.9 \%)$ & $163269(6.2 \%$ en coalición) & $555239(19.6 \%$ en coalición) \\
\hline No registrados & $3181(0.1 \%)$ & $3287(0.1 \%)$ & $16901(0.5 \%)$ \\
\hline Nulos & $59081(2.4 \%)$ & $48736(1.8 \%)$ & $62109(2.1 \%)$ \\
\hline Totales & 2405261 & 2623960 & 2889406 \\
\hline Abstención & $16.5 \%$ & $31.9 \%$ & $38.2 \%$ \\
\hline
\end{tabular}

FUENTE: IFE.

otro tapatío llegó hasta 42.6 puntos. Las mejores votaciones por Andrés Manuel López Obrador, correspondientes a 25\%, se dieron en los distritos del sur de Jalisco, donde este candidato se colocó a sólo un punto por debajo del segundo sitio. El PRI tuvo 224785 más votos en la elección de diputados que en la de presidente. Por el candidato a presidente del PRD votaron 188318 más que para diputados de ese partido.

El Partido Nueva Alianza alcanzó en la elección presidencial 37032 (1.3\%), en la de senadores de representación proporcional obtuvo $132510(4.5 \%)$ y en la de diputados de mayoría relativa 147764 (5.1\%), por lo que 110732 que habían votado por candidatos de ese partido no lo hicieron por su opción presidencial. La votación de Alternativa se comportó de la siguiente forma: 93527 (3.3\%) votaron por su candidata a la presidencia; $54220(1.8 \%)$ sufragaron por sus candidatos al senado en Jalisco, y 58884 (2\%) lo hicieron por sus candidatos a diputados federales. En Nueva Alianza, 110732 que votaron por diputados de esa opción no refrendaron un voto similar por la presidencia. Es decir, las diferencias negativas para las candidaturas presidenciales de los partidos cuyos candidatos estuvieron por debajo de otras opciones del mismo signo partidista (que son 335517 votos) se fueron a los partidos que tuvieron diferencias positivas a favor de sus candidatos presidenciales. El PRD captó 188318 de esos votos, el PAN 105745 y Alternativa 34643. Es posible que la mayoría de los votos de Nueva Alianza se hayan encaminado hacia Felipe Calderón, mientras que una buena parte de votos priístas pasaron a López Obrador y, en menor número, a Patricia Mercado.

\section{Los otros comicios federales}

El porcentaje alcanzado por los senadores panistas es similar al que obtuvieron seis años atrás. Pero un dato relevante fue que el PAN tuvo 11368 más votos en la elección de senadores que en la presidencial, de los cuales 6138 correspondieron al distrito cuya cabecera es Zapotlán el Grande, de donde es originario el candidato panista que encabezaba la primera fórmula, Alberto Cárdenas. Los dos senadores del PAN ganaron ampliamente. El PRI consiguió el escaño de primera minoría. Aunque en números absolutos hay un crecimiento de la votación por diputados panistas, en números relativos hay una pérdida de 3.7 puntos. En el PRI hay una baja en números absolutos y relativos. En el caso de diputados, el PRI desciende cuatro puntos. En cambio, el PRD aumenta votos y asciende 4.7 puntos.

En las elecciones para diputados federales, el PAN ganó 18 distritos. El PRI sólo obtuvo una victoria, en el distrito encabezado por Zapotlán el Grande, donde superó por 5.4 puntos al PAN. En la elección federal, el PAN alcanzó 45.6\%. En seis distritos de los 19 se colocó por encima de 50\% (en dos distritos de Guadalajara, en dos distritos zapopanos y en los dos alteños). El PRI obtuvo 32\%; el mejor porcentaje lo logró en el distrito VII, cuya cabecera 
se encuentra en Tonalá, con 36.1\%. En la elección de diputados federales, el PRD se situó en $12.6 \%$. En seis distritos logró sus mejores porcentajes, que oscilaron entre $16.2 \%$ y $19 \%$ (el norteño, el de Puerto Vallarta, uno de Guadalajara, el de Zapotlán el Grande, el de Autlán y el de Jocotepec). Nueva Alianza alcanzó 5.1\%. Su mejor porcentaje, con 7.1\%, se ubicó en un distrito de Guadalajara. Alternativa se quedó en dos puntos porcentuales. Su mejor votación la tuvo en un distrito tapatío, con $2.6 \%$. Los votos nulos llegaron a 2.2\%. El mayor porcentaje de ellos se situó en el distrito de Lagos, con 3.2\%. En las elecciones federales hubo dos distritos (el norteño I y el de Tonalá) donde la distancia a favor del PAN con respecto del PRI fue de menos de cinco puntos. En cuatro distritos la distancia estuvo entre 6 y 9.9 (el de Jocotepec, el de Autlán, el de Tlajomulco y uno de los distritos populares zapopanos). En cinco distritos la distancia fue de entre 10 y 20 puntos (el encabezado por La Barca, tres de Guadalajara y el de Tlaquepaque). En otros cinco distritos la distancia superó los 20 puntos (el residencial de Zapopan, otro popular zapopano, uno de Guadalajara y los dos alteños).

\section{LOS COMICIOS PARA GOBERNADOR}

Quienes tenían derecho a votar por senadores de mayoría relativa también lo tenían para votar por gobernador, pero hubo 16821 más votos por senadores que por gobernador. También hubo 3600 votos de más para la elec- ción de diputados federales de mayoría relativa que para la de gobernador. En la única elección en la que la votación es menor que la de gobernador es la de diputados locales. En la elección para gobernador de 2006, el PAN aseguró un tercer periodo. En números relativos perdió tres décimas en relación con la elección inmediatamente anterior, pero 7.6 puntos respecto a la primera elección ganada por el PAN, la cual permanece como una marca. En 1995 el PRI quedó a 15.6 puntos debajo del PAN, cuando más de la mitad de los electores optó por el blanquiazul. En las siguientes elecciones el PRI ha recuperado votantes. En el año 2000 el PRI estuvo sólo a 2.1 puntos debajo del PAN, pero en 2006 la distancia, aunque corta, se amplió a 3.7. Estas dos elecciones han sido muy disputadas entre estos dos partidos. En 2006 Emilio González superó a Alberto Zamora por 108923 votos; seis años atrás la distancia entre el PAN y el PRI había sido sólo de 46845 votos. El PRD ha mejorado los números absolutos y relativos de sus votantes. En 2006 casi duplicó lo que había obtenido seis años antes. En 2006 la abstención en la elección para gobernador fue 4.2 puntos menor que en los comicios de 2000, pero 9.8 mayor que en 1995 (véase cuadro 3).

En la elección para gobernador, el PRI se puso arriba del PAN en los distritos zapopanos populares IV y VI, en el norteño I, en el XX de Tonalá y en los sureños XVIII y XIX, con 9.2, 7.6, 4.8, 2, 1.6 y 2.3 puntos respectivamente. Si se compara la elección de gobernador con la presidencial, el candidato panista Emilio González tuvo 129 492 votos menos que Felipe Calderón. En cambio, el can-

Cuadro 3. Elecciones para gobernador en Jalisco

\begin{tabular}{l|c|c|c}
\hline & 1995 & 2000 & 2006 \\
\hline PAN & $1113562(52.7)$ & $983502(45.4)$ & $1296745(45.1)$ \\
\hline PRI & $783601(37.1)$ & $936657(43.3)$ & $1187822(41.4)$ \\
\hline PRD & $84162(3.9)$ & $112743(5.2)$ & $224590(7.8)$ \\
\hline Nulos & $48610(2.3)$ & $34736(1.6)$ & $54214(1.8)$ \\
\hline Votación total & 2111414 & 2161879 & 2869322 \\
\hline Abstención & $28.4 \%$ & $42.5 \%$ & $38.2 \%$ \\
\hline
\end{tabular}

FUENTE: Consejo Electoral del Estado de Jalisco (CEEJ); Instituto Electoral del Estado de Jalisco (IEEJ). 
Cuadro 4. Votaciones presidenciales y por gobernador en Jalisco

\begin{tabular}{|c|c|c|c|c|}
\hline Distritos & $\begin{array}{c}\text { PAN } \\
\text { (comicios presidenciales) }\end{array}$ & $\begin{array}{c}\text { PAN } \\
\text { (comicios por gobernador) }\end{array}$ & $\begin{array}{c}P R I \\
\text { (comicios presidenciales) }\end{array}$ & $\begin{array}{c}\text { PRI } \\
\text { (comicios por gobernador) }\end{array}$ \\
\hline I & 55577 (39.3) & $52509(37.5)$ & $41448(29.3)$ & $59227(42.3)$ \\
\hline II & $79495(57.5)$ & $72575(53.2)$ & $34124(24.7)$ & $44692(32.7)$ \\
\hline III & $93040(62.4)$ & $81950(55.7)$ & 35735 (23.9) & $51878(35.2)$ \\
\hline IV & $70621(47.5)$ & $49479(39.4)$ & $37391(25.1)$ & $60903(49.1)$ \\
\hline $\mathrm{V}$ & $62942(45.2)$ & 56964 (41.9) & $36944(26.5)$ & $55467(40.8)$ \\
\hline VI & $94091(56.2)$ & $65472(40.8)$ & $37129(22.2)$ & $77684(48.5)$ \\
\hline VII & $56023(44)$ & $63549(43.9)$ & $36112(28.4)$ & $59085(40.8)$ \\
\hline VIII & $102005(55.6)$ & $67006(46.4)$ & 35058 (19.1) & $63884(44.2)$ \\
\hline IX & $75966(48.1)$ & $58417(44.5)$ & $35402(22.4)$ & $56028(42.7)$ \\
\hline $\mathrm{X}$ & 93008 (59) & $98394(53.7)$ & 28857 (18.3) & 70678 (38.6) \\
\hline $\mathrm{XI}$ & $69449(45)$ & $59354(44.6)$ & 38239 (24.7) & $58556(44)$ \\
\hline XII & $69502(43.8)$ & $79590(52.4)$ & $44786(28.2)$ & $59533(39.1)$ \\
\hline XIII & $88500(51.2)$ & $61612(45.5)$ & $36706(21.2)$ & $60001(44.3)$ \\
\hline XIV & 91715 (55) & $61153(47.4)$ & 32879 (19.7) & $52496(40.7)$ \\
\hline $\mathrm{XV}$ & $75649(52)$ & $70555(49.4)$ & $35743(24.6)$ & $53514(37.4)$ \\
\hline XVI & $72153(48.5)$ & $69646(44.4)$ & $37669(25.3)$ & $67163(42.8)$ \\
\hline XVII & $63183(41.6)$ & $59240(39.8)$ & 40979 (27) & $59161(39.8)$ \\
\hline XVIII & $61181(40.7)$ & $57359(38.8)$ & $39857(26.5)$ & $59787(40.4)$ \\
\hline XIX & $61234(39.8)$ & $58206(38.2)$ & $40868(26.5)$ & $61741(40.5)$ \\
\hline XX (sólo local) & & $53715(42.7)$ & & $56344(44.8)$ \\
\hline
\end{tabular}

FUENTE: IFE, IEEJ.

didato priísta Arturo Zamora tuvo 489443 votos más que Roberto Madrazo ${ }^{24}$. Esa diferencia equivale a 70\% de lo que logró en Jalisco el candidato presidencial priísta. En ningún distrito la votación de Madrazo fue superior a la de Zamora. Los distritos federales y locales no son enteramente comparables porque hubo cambios y no se corresponden. Hay semejanzas en algunos, sobre todo en los distritos lejanos a la zona metropolitana. En

alto.

24 Las distancias entre los votos cosechados por Zamora y Madrazo le dan una ventaja al primero de entre 20 y 26 puntos en los tres distritos zapopanos y en dos de Guadalajara. distritos que sí pueden compararse —el norteño I y el sureño XIX-, el candidato priísta por la gubernatura obtuvo 3650 votos más que el candidato presidencial panista en el primero, y 507 votos más en el XIX.

Emilio González superó a Zamora en 14 de los distritos jaliscienses locales. Conviene apuntar que en el distrito XVII, Emilio estuvo arriba de Zamora por sólo 79 votos, equivalentes a 0.05 puntos. En uno de los distritos de Guadalajara el PAN apenas alcanzó una ventaja de 0.6. En otros tres distritos de Guadalajara esa distancia va de uno a dos puntos. Esto es relevante, dado que Emilio González venía de ser presidente municipal de Guadala- 


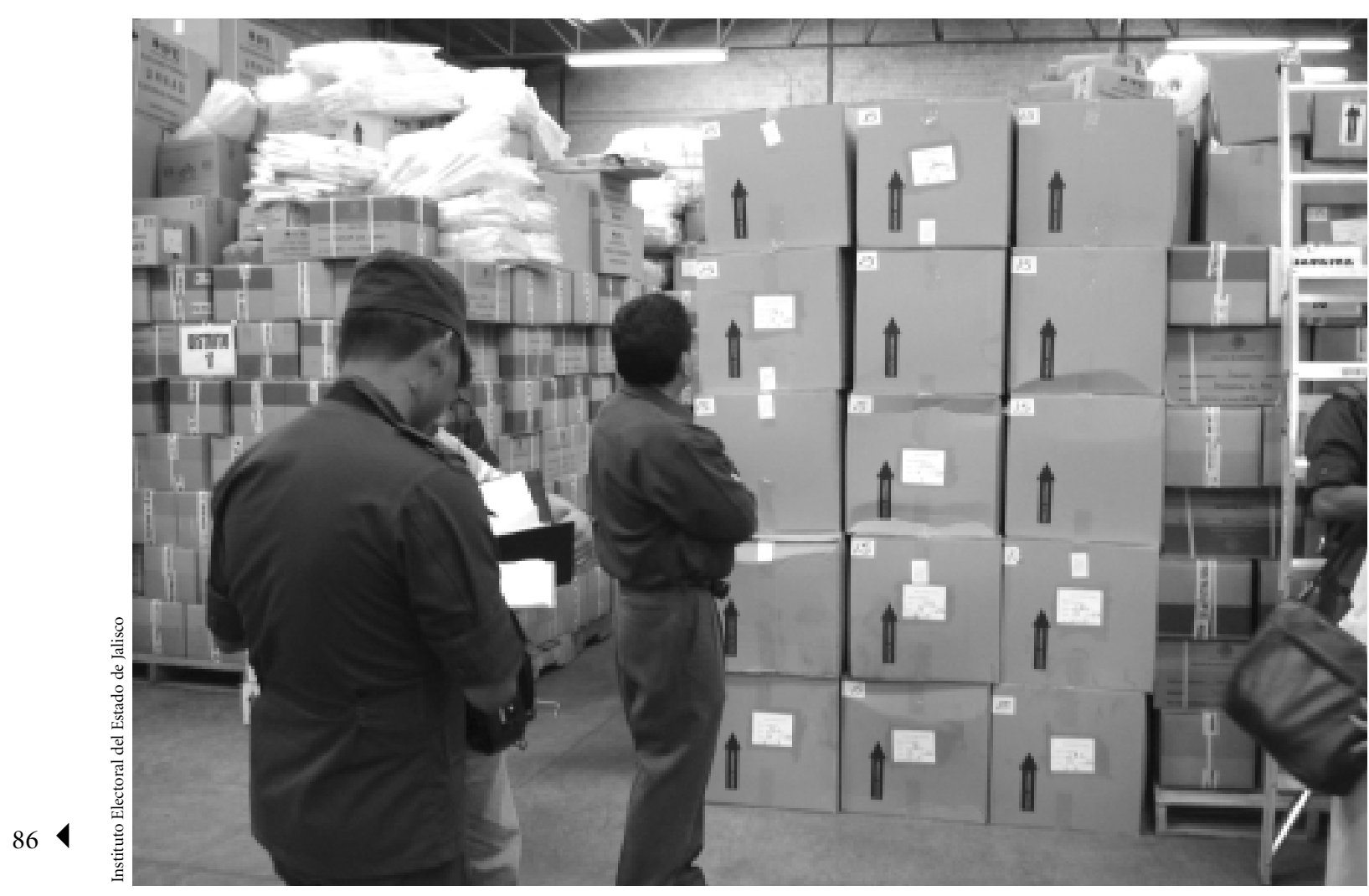

Proceso electoral de julio de 2006 en Jalisco.

jara. Otro distrito donde la ventaja panista es apenas de un punto es el de Puerto Vallarta. No obstante, en un municipio tapatío la distancia se acrecienta a 6.7; en el ribereño XV consigue 12 puntos de ventaja, y en municipios de la zona conurbada llega a 13.3 puntos. Emilio le gana a Zamora, que había sido presidente municipal de $\mathrm{Za}-$ popan, en la zona residencial de ese municipio por 15 puntos $^{25}$. La mejor votación panista, sin competencia, se encuentra en los dos distritos alteños, donde la ventaja es 20.5 puntos (véase cuadro 4, p. 85). En número de votos, el candidato panista obtuvo la más alta votación en

\footnotetext{
${ }^{25}$ La ventaja que había conseguido Zamora respecto de Emilio González en los dos distritos zapopanos superó los 23 mil votos. Pero, como este último estuvo por arriba de Zamora en el distrito residencial de Zapopan, con cerca de 28 mil sufragios, en el territorio zapopano resultó ganador el PAN con más de cuatro mil votos en la elección de gobernador.
}

el distrito residencial zapopano, pues casi llegó a los 100 mil votos. Su segunda votación más alta la tuvo en el distrito alteño de Tepatitlán, donde superó los 80 mil votos. La tercera más alta, con casi esa misma cantidad, estuvo en un distrito de la zona metropolitana, el encabezado por Tlajomulco.

El PAN consiguió en la elección para gobernador votaciones de entre 60 y 72 mil votos en los siguientes distritos: en el alteño con cabecera en Lagos, en el ribereño de Chapala, en tres de Guadalajara y en tres de la zona metropolitana. Tuvo entre 50 y 59 mil votos en los demás distritos. Por su parte, Zamora logró su más copiosa votación en el distrito popular VI de Zapopan, con cerca de 78 mil votos. Su segunda mejor votación se situó en el distrito residencial zapopano, con arriba de 70 mil votos. Obtuvo votaciones de entre 60 y 68 mil en dos distritos de Guadalajara, en otros dos de la zona metropolitana y 
en el sureño XIX. A excepción del distrito alteño de Lagos, donde no llegó a los 45 mil votos, en el resto de los distritos el PRI tuvo votaciones de entre 52 y 60 mil votos en la elección de gobernador. En los seis distritos en que el PRI estuvo por arriba del PAN, la ventaja que acumuló fue de 39 mil votos. No obstante, en los dos distritos alteños, el PAN superó al PRI con 58 mil votos; y en otros dos distritos metropolitanos, el X y el XII, la ventaja panista alcanzó los 48 mil votos, cifras muy superiores a la diferencia albiazul lograda en los cinco distritos tapatíos, que no llegó a los 17 mil votos.

\section{LOS COMICIOS POR DIPUTADOS}

En la elección de diputados locales, el PAN triunfó en 19 de los 20 distritos. El PRI sólo ganó el sureño distrito XIX. Si en la elección de diputados federales el PRI había tenido 268282 votos menos que en la elección para gobernador, en el caso de las elecciones de diputados locales por mayoría relativa el PRI tuvo 238059 votos menos. Es decir, 22.5\% de los que votaron por Zamora no lo hicieron por los diputados federales priístas y repartieron sus votos entre los demás partidos. En el caso de los diputados locales, eso sucedió para $20 \%$ de los que votaron por el candidato priísta a gobernador. Dicho de otra forma, uno de cada cinco votantes por Zamora ya no quiso apoyar a otros candidatos prístas. En cambio, el PAN consiguió 14983 votos más en la elección de diputados federales que en la de gobernador, pero 45107 votos menos en la de diputados locales de mayoría relativa que para la de gobernador, que se fueron a otros partidos. En los comicios para diputados federales la distancia del PAN sobre el PRI fue de 13.6 puntos; en los comicios para diputados locales fue de 10.5 .

$\mathrm{Al}$ ser elecciones concurrentes, deberían haber concordado las cifras entre totales de diputados. No obstante, 8520 personas que votaron para diputados federales ya no lo hicieron para diputados locales. Así, 60090 que votaron por el PAN en federales ya no lo hicieron por diputados locales de ese partido. Hubo 30223 más que votaron por diputados locales priístas que por federales. Aun sumando la votación de Convergencia, hay una diferen-
Cuadro 5. Elecciones de diputados federales y locales en Jalisco por el principio de mayoría relativa

\begin{tabular}{l|c|c}
\hline & Diputados federales & Diputados locales \\
\hline PAN & $1311728(45.6)$ & $1251638(43.6)$ \\
\hline PRI & $919540(32)$ & $949763(33.1)$ \\
\hline PRD & $364345(12.6)$ & $293847(10.2)$ \\
\hline Nueva Alianza & $147764(5.1)$ & $132218(4.6)$ \\
\hline Alternativa & $58884(2)$ & $41585(1.4)$ \\
\hline Nulos & $64611(2.2)$ & $62834(2.1)$ \\
\hline Totales & 2872922 & 2864402 \\
\hline
\end{tabular}

FUENTE: IFE, IEEJ.

cia de 42726 votos más en la votación por la Coalición por el Bien de Todos en federales respecto de las locales. Para Nueva Alianza, de 15546 personas que votaron por candidatos en las federales, en las locales ya no lo hicieron por ese partido. En el caso de Alternativa, 17299 que votaron por esa opción en las federales ya no lo hicieron en las locales. El Partido Verde, que en las federales fue coaligado con el PRI, estuvo por su cuenta en las locales. Hubo 1777 votos nulos más en las federales que en las locales. Alrededor de 130 mil ciudadanos que habían votado por el PAN, la Coalición, Nueva Alianza y Alternativa en la elección de diputados federales cambiaron su voto hacia el PRI y el Partido Verde Ecologista de México (PVEM) en las elecciones de diputados locales (véase cuadro 5).

En las elecciones de diputados locales el PAN obtuvo $43.6 \%$ de los votos. En tres distritos sus porcentajes son superiores a 50\% (Tepatitlán, Tlajomulco y Zapopan, donde se encuentra la zona residencial). El PRI se queda 10.5 puntos por debajo, con $33.1 \%$. Su mejor porcentaje lo tiene en el distrito de Tonalá con 38\%. El PRD-PT consigue $10.1 \%$. Sus mejores porcentajes, entre 15 y $16 \%$, los tiene en los distritos de Zapotlán el Grande, Autlán y Jocotepec. Nueva Alianza se coloca con 4.6\%. Su mejor porcentaje lo obtiene en el distrito de Autlán, con 6.9\%. Alternativa se queda por debajo del punto y medio. $\mathrm{Su}$ mejor porcentaje, con $2.4 \%$, lo tiene en un distrito tapatío. Los votos nulos llegan a $2.1 \%$. Su porcentaje más alto se encuentra en el distrito I, con $2.8 \%$. 
En las elecciones de diputados locales, seis distritos estuvieron muy competidos con distancias pequeñas. El PAN ganó con dos décimas el distrito norteño. La única victoria del PRI es con 1.3 puntos en el distrito sureño de Zapotlán el Grande. El distrito de Tonalá fue para el PAN con 1.6 de diferencia. Entre 3 y 4 puntos se encuentran el de Puerto Vallarta, los dos populares de Zapopan y el de Jocotepec. Otros cuatro distritos se colocan en las distancias que van entre 5 y 10 puntos; se trata de Autlán, Tlaquepaque, otro de la zona metropolitana y uno de Guadalajara. Siete distritos se encuentran entre los $10 \mathrm{y}$ 20 puntos de distancia; son cuatro de Guadalajara, el de La Barca y los dos alteños. El residencial zapopano alcanza los 30 puntos de diferencia a favor del PAN. En las dos elecciones, los distritos norteño y de Puerto Vallarta tienen comportamientos equiparables. En ambas elecciones los distritos alteños muestran diferencias muy elevadas, cerca de los 20 puntos en las locales y alrededor de 25 en las federales. También el residencial zapopano se ubica entre los 20 y 30 puntos de distancia. En donde se da una gran diferencia es en Zapopan, donde se ubica la cabecera de ese municipio, pues en la local la distancia no llega a los cuatro puntos y en la federal es de 23 (véase cuadro 6). O para ponerlo en votos, 20522 personas que sufragaron por el diputado federal panista ya no lo hicieron por el diputado local del mismo partido; y por el diputado local prísta votaron 10868 más de los que habían sufragado por esa misma opción para diputado federal.

Entre la votación de diputados federales por mayoría relativa y los locales hay una diferencia de 8520 votos a favor de la primera elección. Pero si se cuenta por partidos, en distritos comparables se encuentra lo siguiente: en el distrito norteño el PAN pierde 6183 votos en la local respecto de la federal; el PRI, 62; el PRD-PT pierde 2 519; Nueva Alianza pierde 1736 ; Alternativa pierde 851. Hay 323 más votos en la elección local que en la federal. Todos esos votos van al PVEM, que en la local compitió por su cuenta y que obtiene en ese distrito 11 448; Convergencia, que no fue con el PRD-PT, como en el caso federal, logra 872 votos. En el distrito alteño con cabecera en Lagos el PAN pierde en la local respecto de la federal 7856 votos; el PRI gana 667; la Coalición PRD-PT pierde 783 votos; Nueva Alianza pierde 2519 , y Alternativa, 960. En la
Cuadro 6. Distancias entre la votación más alta y la siguiente en elecciones para diputados federales y locales

\begin{tabular}{l|c|c}
\hline Distritos & Federales & Locales \\
\hline I & 4.6 & 0.2 \\
\hline II & 24.4 & 18.1 \\
\hline III & 25.2 & 17.8 \\
\hline IV & 9.9 & 3.8 \\
\hline V & 3.8 & 3 \\
\hline VI & 22.7 & 3.7 \\
\hline VII & 4.6 & 8.5 \\
\hline VIII & 24 & 15.3 \\
\hline XIX & 13 & 10.7 \\
\hline X & 23.7 & 29.6 \\
\hline XI & 10.3 & 8.5 \\
\hline XII & 5.8 & 26.7 \\
\hline XIII & 17.5 & 11.9 \\
\hline XIV & 27.1 & 14 \\
\hline XV & 11.6 & 12.3 \\
\hline XVI & 16.1 & 8.5 \\
\hline XVII & 7.7 & 3.8 \\
\hline XVIII & 6.4 & 7.6 \\
\hline XIX & 5.4 a favor del PRI & a favor del PRI \\
\hline XX local & & 1.6 a favor del PAN \\
\hline & & \\
\hline
\end{tabular}

FUENTE: IFE, IEEJ.

elección federal hay 622 votos más que en la local. Por su parte, el PVEM obtiene 8209 votos y Convergencia, 831 . En el distrito alteño III con cabecera en Tepatitlán, el PAN pierde en la local respecto de la federal 6246 votos. El PRI alcanza 4669 votos más; el PRD-PT pierde 1 465; Nueva Alianza pierde 1766 ; Alternativa, 625. En la federal hay 358 más votantes que en la local. En cambio, el Verde obtiene 5030 y Convergencia, 276 votos. En el distrito de Puerto Vallarta, en la federal respecto de la local, el PAN cuenta con 772 votos menos. Dicho de otra forma, en la local aumentó esos votos. El PRI gana en la local 2111 votos. En cambio, el PRD-PT pierde en la local 8159 votos. Nueva Alianza también pierde 901 y Alternativa, 986. 
Cuadro 7. Elecciones de diputados locales en Jalisco

\begin{tabular}{|c|c|c|c|}
\hline & Diputados locales 2000 & Diputados locales 2003 & Diputados locales 2006 \\
\hline PAN & $1023162(45.5)$ & $883026(39.4)$ & $1251638(43.6)$ \\
\hline PRI & $861228(38.3)$ & $895115(39.9)$ & $949763(33.1)$ \\
\hline PRD & $170638(7.5)$ & $158659(7)$ & $293847(10.2)$ \\
\hline PT & $42520(2)$ & $31728(1.4)$ & \\
\hline PVEM & $53428(2.3)$ & $198491 \quad(8.8)$ & $99784(3.4)$ \\
\hline Convergencia & $11550(0.5)$ & $12976(0.5)$ & $27772(0.9)$ \\
\hline Nueva Alianza & & & $132218(4.6)$ \\
\hline Alternativa & & & $41585(1.4)$ \\
\hline
\end{tabular}

FUENTE: CEEJ, IEEJ.

En la federal hay 1324 más votantes. En ese distrito, el PVEM consigue 5639 votos y Convergencia, 907. En el distrito XV con cabecera en La Barca el PAN pierde en la local 1348 votos; el PRI, 2 298; el PRD-PT, 1213; Nueva Alianza, 69 y Alternativa, 495. En la local hay 136 votantes más que en la federal. El Verde obtiene 4480 y Convergencia, 1020 votos. En el distrito XVIII, con cabecera en Autlán, el PAN pierde en la local 2201 votos; el PRI, 4 087; el PRD-PT, 2 252; Alternativa, 1 029, pero Nueva Alianza gana 2 524. En la federal hay 383 más votantes. El Verde alcanza 5358 y Convergencia, 1836. Finalmente, en el distrito XIX con cabecera en Zapotlán el Grande, el PAN pierde en la local 2651 votos; el PRI, 8 766; el PRD-PT, 2 625; Alternativa, 838, pero Nueva Alianza gana 583. Hay en la federal 536 más votantes. Aquí el Verde obtiene 7258 y Convergencia, 6 567. Cuando entran otros contendientes se recompone la votación. En el estado el PAN pierde 60090 votos y dos puntos en la elección local. El PRI aumenta su votación en 30223 y un punto; el PRD-PT pierde 70498 votos y dos puntos y medio; Nueva Alianza pierde 15546 votos y medio punto; Alternativa pierde 17299 y poco más de medio punto. En cambio, el Verde obtiene 99784 votos y 3.4 puntos, y Convergencia, 27772 votos y un punto.

Resumiendo, en dos distritos (el norteño y el ribereño) hay más votos en la elección por diputados locales que en la de diputados federales, pero todos los partidos pierden votos, que son aprovechados por los partidos que localmente se escindieron de sus alianzas nacionales. En los distritos alteños el PRI consigue más votos en la elección local que en la federal. En el distrito costeño $V$, tanto el PAN como el PRI mejoran el desempeño que tuvieron en los comicios federales. En los sureños XVIII y XIX Nueva Alianza obtiene más votos que en la elección federal. Esto es más significativo en el distrito XVIII. No habría que olvidar que en ese distrito es donde tuvo su mayor porcentaje de representantes.

Conviene recordar el historial electoral. El PRI ganó los 20 distritos locales en 1988 y 1992. En 1995 el PRI sólo ganó tres de los 20 distritos. En 1997 se recuperó y consiguió la victoria en 11. En el año 2000 bajó a seis. En 2003 volvió a elevar sus triunfos hasta 14, y en 2006 sólo obtuvo uno. Los distritos sólo han sigo ganados por el PAN y el PRI. Los demás partidos nunca han conseguido un diputado de mayoría (véase cuadro 7).

En el reparto que hizo el organismo electoral de los diputados de representación proporcional, al PAN le tocaron dos, que sumados a los 19 de mayoría relativa harían un grupo parlamentario de 21 , lo cual le daba la mayoría en una diputación de 40. Al PRI le fueron asignados 12, y tendrá un grupo parlamentario de 13; el PRD-PT consiguió cuatro (tres perredistas y un petista), y Nueva Alianza, dos. El Partido Verde impugnó que no le hubiera tocado un diputado. Si bien en la votación total se quedaba a dos centésimas del 3.5\% requerido para que entrara en el reparto, en la votación válida superaba esa cifra por seis centésimas. La ley electoral indicaba que se debía tener en cuenta la votación total, pero la Constitu- 
Cuadro 8. Elecciones municipales en Jalisco

\begin{tabular}{l|c|c|c}
\hline & Municipales 2000 & Municipales 2003 & Municipales 2006 \\
\hline PAN & $986177(44.3)$ & $902175(38.9)$ & $1228740(42.9)$ \\
\hline PRI & $854301(38.3)$ & $937569(40.4)$ & $287874(10.1)$ \\
\hline PRD & $179498(8)$ & $163675(7)$ & $94592(3.3)$ \\
\hline PT & $53015(2.3)$ & $29374(1.2)$ & $29975(1)$ \\
\hline PVEM & $54014(2.4)$ & $158817(6.8)$ & $88934(3.1)$ \\
\hline Convergencia & $12903(0.5)$ & $10826(0.4)$ & $28843(1)$ \\
\hline Nueva Alianza & & & \\
\hline Alternativa & & & \\
\hline
\end{tabular}

FUENTE: CEEJ, IEEJ.

ción local marcaba que la votación para el reparto debía ser la válida. El tribunal argumentó que sobre la ley estaba la Constitución. Al darle un diputado de representación proporcional al Partido Verde, se le tuvo que quitar uno al PAN, con lo que este partido perdió la mayoría en el Congreso ${ }^{26}$. No todos los diputados tuvieron un mismo valor porcentual. Al PRI y al PRD sus diputados les costaron 2.5 puntos porcentuales cada uno, a Nueva Alianza, 2.3, y 2.1 al PAN. Las enormes campañas mediáticas tanto nacional como local impactaron a tal punto que Jalisco se volvió a teñir de azul, con excepción del manchón verde del sureño distrito XIX. No obstante, la revisión de las cifras llevan a confirmar que los bastiones panistas siguen siendo la zona de Los Altos y las fracciones de capas medias y altas de la zona metropolitana.

\section{ELECCIONES MUNICIPALES}

Comparando los números totales en la elección de munícipes con los de diputados locales en 2006 tenemos que el PAN perdió 22898 votantes; el PRD también experimen-

\footnotetext{
${ }^{26}$ El PAN jalisciense demostró que en 2007, cuando iniciara la nueva legislatura local, podría remontar esa situación, pues en noviembre de 2006, con promesas de puestos públicos para dos diputados prístas todavía en funciones (y para personas de sus equipos), los atrajo a su fracción parlamentaria. La prensa criticó duramente lo que fue calificado de compra de diputados (Público y Mural, 20 de noviembre de 2006).
}

tó una ligera merma de 5973 votantes, y respecto a Nueva Alianza, 43384 personas que optaron por las fórmulas de diputados ya no refrendaron ese voto en los comicios municipales. Quien acapara esas pérdidas es el PRI, que tiene 90504 más votos en las elecciones municipales que en las de diputados locales. Si comparamos ahora los números globales de las elecciones municipales con las de 2000, el PAN aumentó en números absolutos, pero decreció casi punto y medio; el PRI también aumentó sus números absolutos, aunque perdió dos puntos porcentuales, mientras que el PRD creció en números absolutos y relativos.

En cuanto a los municipios en 1988, el PRI tenía la victoria en 120 de los 124. En 1992 bajó a 106, mientras que el PAN alcanzaba 15. Para 1995 el PRI descendía hasta 63 y el PAN se alzaba con 52. En 1997 hubo más pluralidad: el PAN tuvo 40; el PRI, 70; el PRD, 11; el PT, dos; y el PVEM, uno. En el año 2000 el PAN llegó a 50; el PRI ganó en 64; el PRD en seis y el PVEM en tres. En 2003 el PAN tuvo 51; el PRI, 60; el PRD, cinco; y el PVEM, ocho. En 2006 Jalisco aumentó un municipio y pasó de 124 a 125 . El PAN recuperó la zona metropolitana (tres años atrás se había quedado sólo con Guadalajara) y obtuvo el triunfo en 63 alcaldías; el PRI consiguió 46; el PRD-PT, diez; y el PVEM, cinco. Se dio un empate en un municipio entre el PAN y el PRI (véase cuadro 8).

En 2006 se presentaron 73 cambios con respecto a 2003 (lo que equivale a $58.4 \%$ del total). En 37 municipios el cambio fue hacia el PAN, en 23 hacia el PRI, en diez hacia 


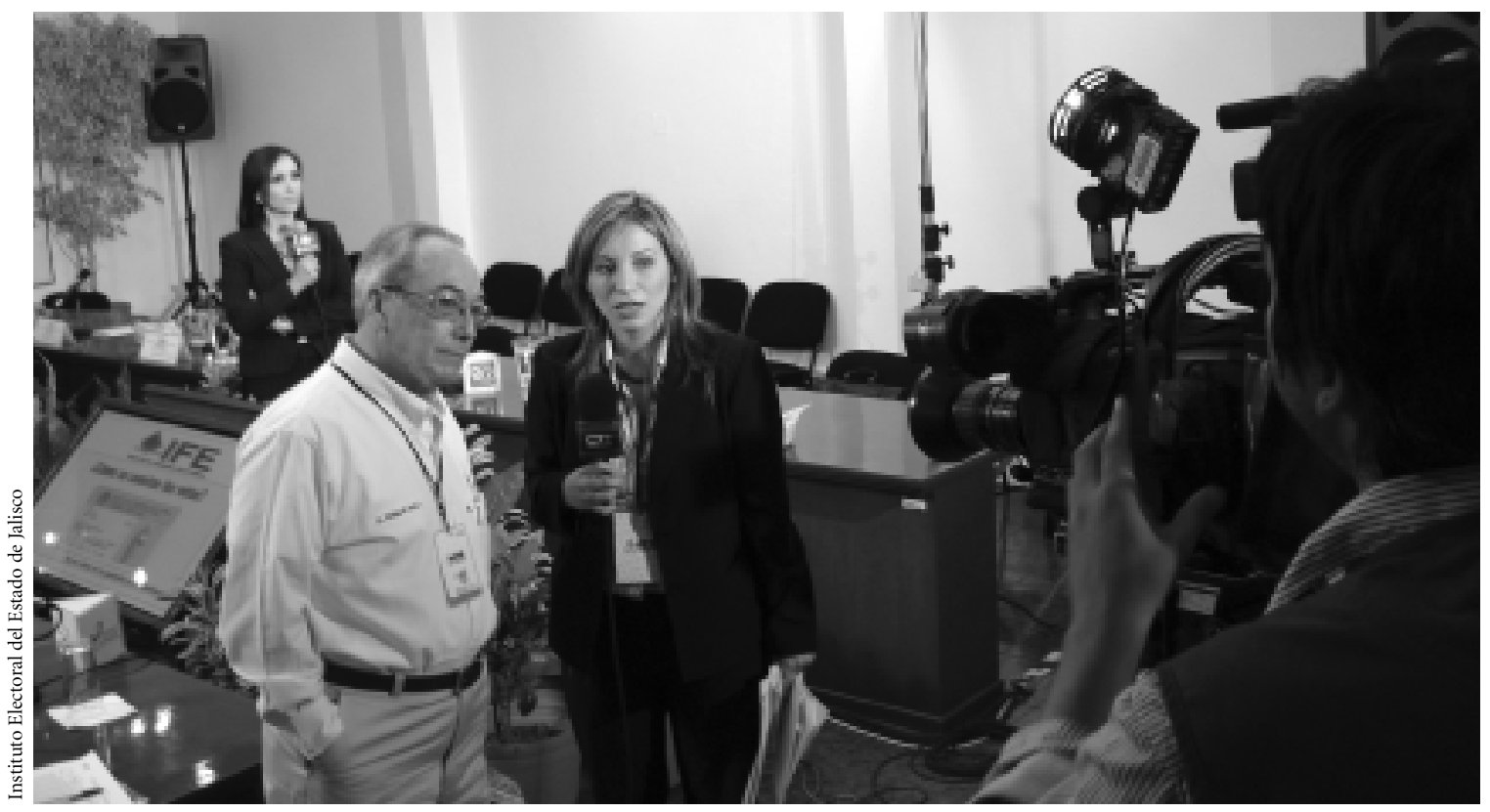

Esteban Garaiz, vocal ejecutivo del Instituto Electoral del Estado de Jalisco.

el PRD y en tres al Verde. Sólo en cuatro municipios pequeños no ha habido alternancia y prosigue el dominio del PRI. En Santa María de los Ángeles el PAN ha ganado seis veces consecutivas. En Guadalajara, Tepatitlán, Santa María del Oro y Jalostotitlán, por quinta ocasión consecutiva refrendó su triunfo el PAN. En Talpa, Zacoalco, El Grullo y Teocaltiche, el PRI consiguió su cuarto triunfo consecutivo. El PVEM refrendó su triunfo en dos municipios. El PRD ganó nuevos, pero no mantuvo el triunfo en los municipios que había ganado en 2003. En 50 municipios (40\%) los ciudadanos refrendaron al partido que los había gobernado.

Persiste una tendencia bipartidista. En los municipios donde los triunfos son mayores a 50\% y donde gana el PAN, el competidor más cercano es el PRI; y donde el PRI es el triunfador, los segundos sitios son del PAN. En los municipios donde los partidos ganadores lo hacen con un porcentaje entre 40.1 y $50 \%$ también existe ese enroque entre el PRI y el PAN, menos en cuatro municipios donde el segundo sitio corresponde a la alianza del PRDPT. Lo mismo sucede en los casos en que las victorias se colocan entre 35.1 y $40 \%$, con excepción de un municipio en el que el segundo lugar es para el PVEM. Hay $30 \mathrm{mu}-$ nicipios donde quien obtiene el triunfo lo hace gracias a que dos opositores dividieron sus votos. En cuatro municipios hubo competencia entre cuatro contendientes. En Cuquío el PRI se alza con la victoria con 22.3\% frente al PRD que obtiene $21.9 \%$, el PAN 21.1\% y Nueva Alianza $20.9 \%$. En Sayula el voto se dispersó entre seis partidos. También en Tuxpan el voto se dividió entre seis contendientes y al ganador le bastó $21.2 \%$ de los votos.

En la zona metropolitana el PAN triunfó con amplia ventaja (en Tlajomulco con 11.1, en Guadalajara con 10.5, en Zapopan con 9 y en Tlaquepaque con 8.3). En Tonalá la contienda fue más competida pues el PAN ganó con 3.6 de ventaja. Hay municipios muy reñidos donde la distancia entre el ganador y el que le sigue es muy estrecha. En Atenguillo el PRI obtiene una ventaja sobre el PAN de sólo una décima y dos votos. En Bolaños también la distancia entre esos dos partidos es de una décima y cuatro votos. En Pihuamo la diferencia es de dos décimas y tres votos; en Atemajac, de tres décimas y nueve votos; en Encarnación, de dos décimas y 37 votos. El PRI gana Ayotlán sólo con 6 décimas de ventaja, Cuquío con 1.2, Zacoal- 
Cuadro 9. Porcentajes con los que se triunfa en 2006 en los municipios jaliscienses

\begin{tabular}{|c|c|c|c|c|}
\hline Superior al 60\%: 3 & $\begin{array}{l}\text { PAN: } 2 \\
\text { Ayutla, } 77 \\
\text { San Julián, } 65\end{array}$ & $\begin{array}{l}\text { PRI: } 1 \\
\text { El Grullo, } 60.3\end{array}$ & & \\
\hline $\begin{array}{l}\text { Entre } 50.1 \text { y } 60 \%: \\
25\end{array}$ & $\begin{array}{l}\text { PAN: } 18 \\
\text { Lagos, Ocotlán, } \\
\text { Tepatitlán, Atotonilco, } \\
\text { Atoyac, Cañadas } \\
\text { Obregón, Concepción } \\
\text { de Buenos Aires, } \\
\text { Degollado, Jalostotitlán, } \\
\text { Jesús María, Mextica- } \\
\text { cán, San Diego, Santa } \\
\text { María del Oro, Tene- } \\
\text { maxtlán, Tonaya, Valle } \\
\text { de Guadalupe, Yahuali- } \\
\text { ca, Zapotlajeno }\end{array}$ & $\begin{array}{l}\text { PRI: } 7 \\
\text { Amacueca, Cabo Co- } \\
\text { rrientes, Cuautla, Gua- } \\
\text { chinago, San Martín de } \\
\text { Bolaños, Talpa, Teo- } \\
\text { cuitatlán }\end{array}$ & & \\
\hline $\begin{array}{l}\text { Entre } 40.1 \text { y } 50: \\
57\end{array}$ & $\begin{array}{l}\text { PAN: } 32 \\
\text { Guadalajara, Zapopan, } \\
\text { Tlaquepaque, Tonalá, } \\
\text { Tlajomulco, Zapotlán el } \\
\text { Grande, Acatic, Arandas, } \\
\text { Atengo, Autlán, Chiqui- } \\
\text { listán, Colotlán, Cuauti- } \\
\text { tlán, Ejutla, Hostotipa- } \\
\text { quillo, Ixtlahuacán de los } \\
\text { Membrillos, Huequilla el } \\
\text { Alto, Juchitlán, Mezqui- } \\
\text { tic, Mixtlán, San Juanito, } \\
\text { San Miguel el Alto, Santa } \\
\text { María de los Ángeles, } \\
\text { Tamazula, Tecalitlán, Te- } \\
\text { quila, Tonila, Tototlán, } \\
\text { Unión de San Antonio, } \\
\text { Valle de Juárez, Villa Hi- } \\
\text { dalgo, Villa Purificación }\end{array}$ & $\begin{array}{l}\text { PRI: } 20 \\
\text { Puerto Vallarta, El Salto, } \\
\text { Juanacatlán, Atemajac, } \\
\text { Atenguillo, Ayotlán, Bo- } \\
\text { laños, Chapala, Encar- } \\
\text { nación, Jilotlán, Magda- } \\
\text { lena, Mazamitla, Quitu- } \\
\text { pan, San Cristóbal, } \\
\text { Tecolotlán, Teuchitlán, } \\
\text { Tolimán, Villa Guerrero, } \\
\text { Zapotitlán, Zapotlán del } \\
\text { Rey }\end{array}$ & $\begin{array}{l}\text { PRD-PT: } 4 \\
\text { Acatlán, Casimiro Cas- } \\
\text { tillo, La Manzanilla, San } \\
\text { Sebastián }\end{array}$ & $\begin{array}{l}\text { PVEM: } 1 \\
\text { Mascota }\end{array}$ \\
\hline $\begin{array}{l}\text { Entre } 35.1 \text { y } 40: \\
17\end{array}$ & $\begin{array}{l}\text { PAN: } 8 \\
\text { Etzatlán, Gómez Farías, } \\
\text { Jocotepec, San Ignacio } \\
\text { Cerro Gordo (nuevo), San } \\
\text { Juan de los Lagos, Totati- } \\
\text { che, Tuxcacueco, Zapotiltic }\end{array}$ & $\begin{array}{l}\text { PRI: } 6 \\
\text { Chimaltitán, Cihuatlán, } \\
\text { Huejúcar, San Marcos, } \\
\text { Teocaltiche, Unión de Tula }\end{array}$ & $\begin{array}{l}\text { PRD-PT: } 3 \\
\text { Ojuelos, Poncitlán, } \\
\text { Tapalpa }\end{array}$ & \\
\hline $\begin{array}{l}\text { Entre } 30.1 \text { y } 35: \\
15\end{array}$ & $\begin{array}{l}\text { PAN: } 3 \\
\text { Ameca, El Arenal, Jamay }\end{array}$ & $\begin{array}{l}\text { PRI: } 8 \\
\text { La Barca, Amatitán, El Li- } \\
\text { món, San Gabriel, Techa- } \\
\text { luta, Tizapán, Tomatán, } \\
\text { Zacoalco }\end{array}$ & $\begin{array}{l}\text { PRD-PT: } 3 \\
\text { Cocula, San Martín Hi- } \\
\text { dalgo, Tala }\end{array}$ & $\begin{array}{l}\text { PVEM:1 } \\
\text { La Huerta }\end{array}$ \\
\hline $\begin{array}{l}\text { Entre } 25.1 \text { y } 30: \\
\mathbf{5}\end{array}$ & & $\begin{array}{l}\text { PRI: } 3 \\
\text { Ixtlahuacán del Río, Pi- } \\
\text { huamo, Villa Corona }\end{array}$ & & $\begin{array}{l}\text { PVEM: } 2 \\
\text { Sayula, Ahualulco }\end{array}$ \\
\hline $\begin{array}{l}\text { Entre } 20.1 \text { y } 25: \\
2\end{array}$ & & $\begin{array}{l}\text { PRI: } 1 \\
\text { Cuquío }\end{array}$ & & $\begin{array}{l}\text { PVEM: } 1 \\
\text { Tuxpan }\end{array}$ \\
\hline $\begin{array}{l}\text { Empate: } \\
\mathbf{1}\end{array}$ & $\begin{array}{l}\text { PAN: } 1 \\
\text { Tuxcueca }\end{array}$ & $\begin{array}{l}\text { PRI: } 1 \\
\text { Tuxcueca }\end{array}$ & & \\
\hline
\end{tabular}

FUENTE: IEEJ (en negritas municipios importantes).

NOTA: Según los resultados de la jornada electoral, sin los cambios de los tribunales. 
co con 1.5, Huejúcar con 1.7 e Ixtlahuacán del Río con 2.2. Por su parte, el PAN gana Villa Purificación con cinco décimas, Arandas con seis décimas, Villa Hidalgo con 1.2, Juchitlán con 1.6, Ameca con 2 puntos y Ejutla con 2.2. La Coalición del PRD-PT gana Tapala con nueve décimas, San Martín Hidalgo con un punto y Cocula con 2.2. El PVEM alcanza la victoria en Ahualulco con 1.8 puntos de diferencia. El PAN gobernará a ocho de cada diez jaliscienses. Por las elecciones municipales de 2003 el PRI llegó a gobernar a la mitad de los jaliscienses, pero los resultados de 2006 lo circunscribieron a tener el gobierno municipal sobre sólo $14.7 \%$ de jaliscienses (véase cuadro 9, p. 92).

\section{UNA VISIÓN DE CONJUNTO DE LAS SEIS ELECCIONES DE 2006}

El mismo día, los ciudadanos jaliscienses tuvieron que decidir ante seis urnas diferentes. Prácticamente uno de cada dos votó por los candidatos panistas al Senado y a la presidencia de la República. Esto se explica, además de por la intensidad de la campaña, por la aceptación que todavía mantiene el ex gobernador Alberto Cárdenas, quien encabezaba la primera fórmula senatorial. En ambos casos se alcanzaron cifras de 1.4 millones de votos. La tercera mejor votación de candidatos panistas fue en los comicios de diputados federales, aunque el PAN perdió en esa opción más de 100 mil votos y alrededor de cuatro puntos porcentuales. Las elecciones locales no atrajeron tantos votantes. Alrededor de 141 mil que sufragaron por candidatos a senadores, y cerca de 15 mil que votaron por candidatos a diputados federales panistas no apoyaron la elección del gobernador propuesto por el PAN. La pérdida de votantes fue en aumento en el caso de las diputaciones locales, pues alcanzó a 186 mil; para munícipes esto se elevó a 209 mil votantes que optaron por candidatos de otros partidos. En términos porcentuales la pérdida representó siete puntos y medio. En el caso del PRI, sus mejores votaciones son a nivel local y sus peores descalabros se encuentran en los comicios federales. Una tercera parte de los votantes se inclinó por los candidatos priístas al poder legislativo, pero cerca de medio millón (correspondientes a 16.7 puntos) de los que votaron por su candidato a gobernador no lo hicieron por su candidato presidencial. En el caso del PRD-PT fue a la inversa. Su mejor votación fue la presidencial y la más baja la de gobernador; 330649 personas que votaron por López Obrador (el equivalente a 11.8 puntos) no lo hicieron por Ibarra. Si en las elecciones para los poderes legislativos (federal y local) alrededor de uno de cada diez votantes lo hizo por el PRD, para el ejecutivo federal lo hicieron dos de cada diez. Sin embargo, para el ejecutivo local apenas 7.8\% se inclinó por esa opción. En número de regidores el PAN obtuvo el equivalente a 2.1 puntos más que su votación; el PRI medio punto más; el PRD-PT 1.7 puntos más, y el Verde 1.1 más. En este reparto todos los partidos alcanzaron alguna representación, pues Nueva Alianza logró 12 regidores, Convergencia diez y Alternativa cinco. Sin olvidar que las campañas y los candidatos cuentan mucho para los resultados electorales, al comparar el número de votantes por el candidato príista a la gubernatura y por los candidatos panistas a las alcaldías, veremos que hay mucha cercanía (véase cuadro 10, p. 94).

\section{REVISIÓN DE LAS ÚLTIMAS ELECCIONES PARA RENOVACIÓN DEL PODER EJECUTIVO}

Partiendo del primer triunfo en la elección de gobernador en 1995, tanto en esas elecciones como en las presidenciales de 2000 se dio un predominio panista con ventajas de 15.6 y 17.1. En las elecciones para gobernador y para munícipes en 2000 las distancias se acortaron y se ceró la contienda entre el PAN y el PRI, a tal punto que el tricolor superó con punto y medio al blanquiazul en las elecciones municipales de 2003. Los comicios por la gubernatura y por los municipios volvieron a mostrar que esos dos partidos compiten con porcentajes cercanos en 2006. La distancia se abrió en la elección presidencial porque muchos prístas prefirieron a López Obrador sobre Madrazo, con lo que se desplomó su partido y creció la izquierda. No obstante, en los últimos once años se mantiene una competencia bipartidista que propicia que en algunas coyunturas cambie el ganador (véase gráfica 1, p. 95). Los otros opositores tienen una presencia discreta, aunque con una tendencia a la alza y logran hacer un contrapunto. 
Cuadro 10. Las seis elecciones de 2006 en Jalisco

\begin{tabular}{l|c|c|c}
\hline & PAN & PRI & PRD-PT \\
\hline Presidente de la República & $1426237(50.4 \%)(\mathrm{II})$ & $698379(24.7 \%)(\mathrm{VI})$ & $555239(19.6 \%)(\mathrm{I})$ \\
\hline Senadores & $1437605(49.4 \%)(\mathrm{I})$ & $873871(30 \%)(\mathrm{V})$ & $341857(11.7 \%)(\mathrm{III})$ \\
\hline Diputados federales & $1311728(45.6 \%)(\mathrm{III})$ & $919540(32 \%)(\mathrm{IV})$ & $364345(12.6 \%)(\mathrm{II})$ \\
\hline Gobernador & $1296745(45.1 \%)(\mathrm{IV})$ & $1187822(41.4 \%)(\mathrm{I})$ & $224590(7.8 \%)(\mathrm{VI})$ \\
\hline Diputados locales & $1251638(43.6 \%)(\mathrm{V})$ & $949763(33.1 \%)(\mathrm{III})$ & $293847(10.2 \%)(\mathrm{IV})$ \\
\hline Municipios & $1228740(42.9 \%)(\mathrm{VI})$ & $1040267(36.3 \%)(\mathrm{II})$ & $287874(10.1 \%)(\mathrm{V})$ \\
\hline
\end{tabular}

FUENTE: IFE, IEEJ.

\section{DENUNCIA DE FRAUDE ELECTORAL}

Los empresarios jaliscienses y los panistas celebraron los resultados de las elecciones presidenciales. Cuando Calderón visitó Jalisco, los empresarios destacaron que el voto de Jalisco había sido fundamental para que alcanzara el triunfo, por lo que le instaban a que colocara a personas de Jalisco en su gabinete. Pero tanto los militantes que habían apoyado la campaña de López Obrador desconocieron los resultados de las elecciones presidenciales en Jalisco y acusaron que se había realizado un fraude. Hubo una gran cantidad de actos para repudiar el frau$\mathrm{de}^{27} \mathrm{y}$ demandar que los votos se volvieran a contar. En la prensa se fueron planteando diversos reclamos. Hubo quejas de que muchos empresarios habían coaccionado el voto de sus empleados. Se apuntó que hubo zonas donde se registraba más del cien por ciento de votantes. En 18 casos hubo exceso de votos, aun suponiendo la votación de todos los que aparecían en la lista electoral; y esto no sólo en secciones alejadas, pues en una casilla de Guadalajara se denunció el resultado de más votos que votantes ${ }^{28}$. Un consejero electoral distrital narró que en el distrito VIII de Guadalajara, un funcionario había hecho dos

${ }^{27}$ Hubo marchas, plantones, recogida de firmas, actos simbólicos de repudio contra promotores de la guerra sucia y del fraude, como grandes cadenas comerciales y bancos; una militante se desnudó en una de las plazas públicas y en la Universidad de Guadalajara se montó un altar de muertos a la democracia.

${ }^{28}$ Mural, 18 de julio de 2006.

actas, una de acuerdo con lo señalado en la sábana ${ }^{29}$ y otra con 150 votos más para Calderón, que era la que había introducido en el paquete electoral. Pese a que esto se denunció, no fue perseguido ${ }^{30}$. Se llamó la atención sobre la existencia de actas cuyas cifras no correspondían a las que se habían puesto en las sábanas colocadas fuera de las casillas. Como pruebas se mostraban fotografías de dichas sábanas. Cuando esto se denunció, para evitar que los ciudadanos se dieran cuenta de esas inconsistencias, muchas sábanas fueron retiradas.

En una entrevista, el vocal ejecutivo del Instituto Federal Electoral (IFE) en Jalisco declaró que no era descartable el fraude ${ }^{31}$, pero que había que probarlo. En una sesión de análisis electoral apuntó que se había dado una clara intención de distorsionar la voluntad popular. Existió una campaña orquestada desde los grandes poderes fácticos y no sólo de raigambre nacional. Incluso en Jalisco se importaron profesionales "de la guerra sucia", con lo que se violó el artículo 33 constitucional al hacer que extranjeros intervinieran en asuntos nacionales. Precisó que la gran cantidad de dinero que se les pagó no se podía declarar al IFE, pues no había manera de justificarla. Con la guerra sucia se había violado la Constitución y la ley. Denunció la existencia del voto corporativo decisivo para la diferen-

\footnotetext{
${ }^{29}$ Así se denominan las grandes cartulinas que se colocan fuera de los domicilios donde estuvieron las casillas para dar a conocer los resultados electorales.

${ }^{30}$ Reunión de análisis de las elecciones en Casa Clavijero, 24 de agosto de 2006.

${ }^{31}$ Público, 5 de agosto de 2006
} 
Gráfica 1. Elecciones en Jalisco

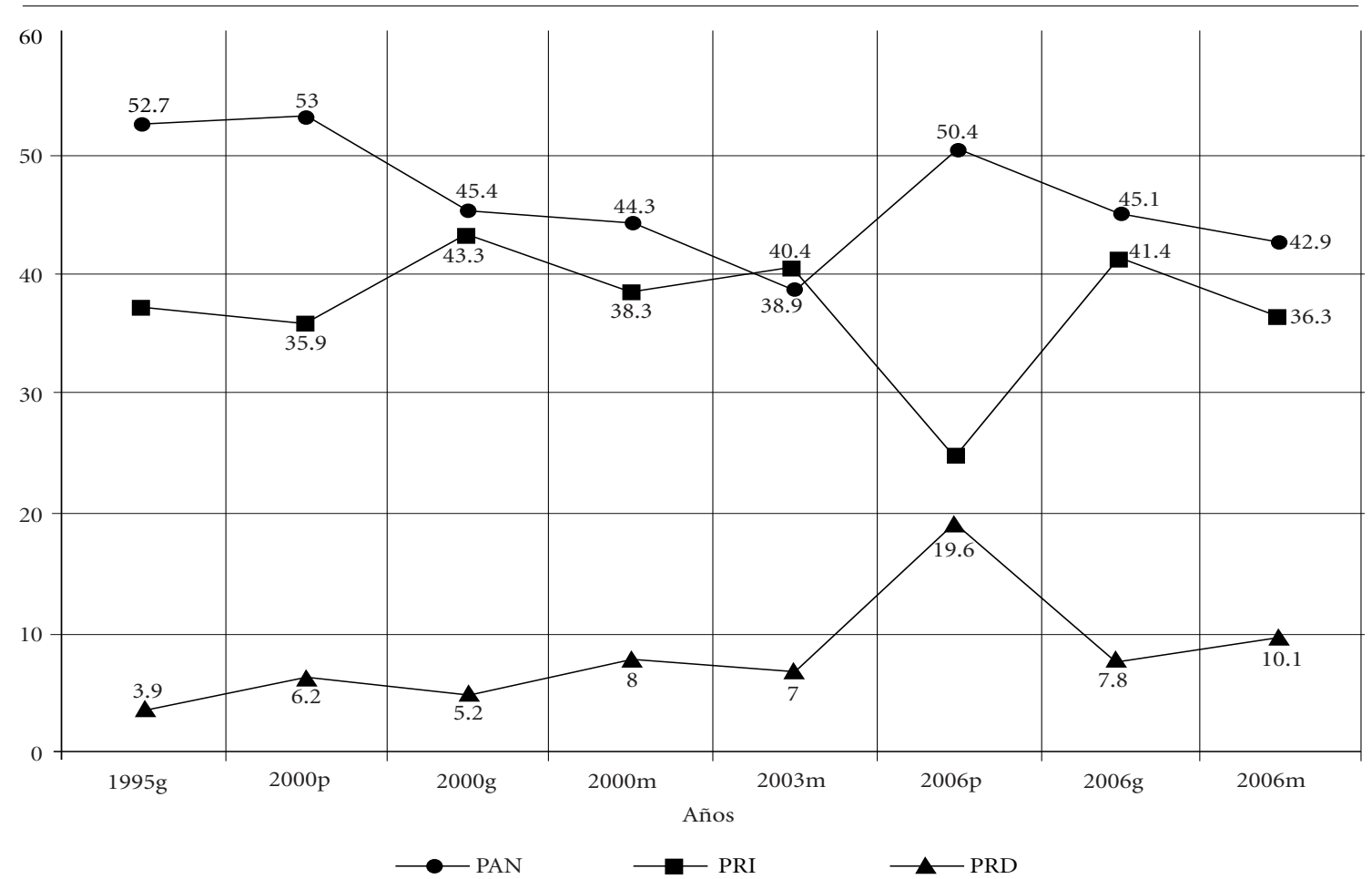

FUENTE: IFE, CEEJ, IEEJ.

NOTA: $g$ corresponde a las elecciones para gobernador, $m$ a las municipales, $\mathrm{y} p$ a las presidenciales.

cia. Reconoció que también hubo "chapucitas" al viejo estilo. Lamentó que el Programa de Resultados Electorales Preliminares (PREP) hubiera sido manoseado deliberadamente y que hubiera inducido a engaño. Reconoció que en algunos casos se dieron graves fallas, como en una casilla en Tepatitlán, donde el presidente y el secretario renunciaron días antes, y una vocal escrutadora había aceptado la presidencia de la casilla cuando sólo contaba con quinto de primaria. El resultado fue que no supo sumar. Otro error que olía claramente a fraude había sido que, en otra casilla, los votos que eran para López Obrador se le habían puesto a Campa. Narró un caso más, en el cual el presidente había cantado 100 votos para López Obrador y la secretaria había puesto 10. Hizo una autocrítica a la capacitación de los funcionarios de casilla. Tras precisar que el mismo día de la elección se habían dado pocas sustituciones de funcionarios (de la fila se habían tomado a 504 ciudadanos), en los días previos sí se había presentado una gran cantidad. Criticó que miembros del Consejo General del IFE hubieran acudido a pedir apoyo a empresarios jaliscienses para impulsar la masiva campaña con la que intentaban usar a los ciudadanos para justificar los errores que les correspondían a ellos ${ }^{32}$. El vocal ejecutivo del IFE, al concluir la sesión de ese organismo en Jalisco el 31 de agosto, resumió:

Estamos concluyendo este azaroso proceso electoral federal que ha dejado al descubierto las profundas diferencias sociales que aquejan desde su origen mestizo a la nación mexicana y que no hemos sido capaces de superar todavía.

\footnotetext{
${ }^{32}$ Reunión de análisis de las elecciones, Casa Clavijero, 24 de agosto de 2006. Pese a la intensa y costosa campaña mediática para posicionar al IFE después de su cuestionada actuación, la encuesta realizada por Parametría, cuyos resultados se dieron a conocer el 9 de noviembre de 2006, reveló que la imagen del IFE cayó 14 puntos.
} 
Las campañas también han exacerbado esas diferencias [...] todos sabemos que no fue una campaña limpia ni equitati$v a$. No se puede impunemente repetir el bochornoso espectáculo de las campañas sucias de este proceso que concluye. Se requieren sanciones severas para la intromisión extranjera en nuestra vida política nacional [...]. Será necesario eliminar de manera expresa las interferencias del Ejecutivo federal frente a candidatos o plataformas electorales que con toda claridad sesgan las condiciones de equidad electoral, así como deben establecerse sanciones claras y severas a la interferencia electoral de empresas o de organismos empresariales en las campañas ${ }^{33}$.

En Guadalajara se sostuvo una reunión regional entre integrantes del Consejo General del IFE y consejeros locales y distritales. Algunos de estos últimos demandaron a los primeros que renunciaran ${ }^{34}$. El 19 de enero el pre-

${ }^{33}$ El Informador, $1^{\circ}$ de septiembre de 2006.

34 De la reunión estatal de consejeros locales y distritales del IFE en Jalisco, que se realizó el 26 de agosto de 2006, se hizo una relatoría de observaciones y sugerencias. En la introducción se recalcaba que en el futuro habría que evitar que el proceso y la jornada electoral fueran motivo de discordia o sospecha. En sus propuestas al poder legislativo federal destacaba la revisión del comportamiento de los medios de comunicación en los procesos electorales. Al IFE se le pedía que tuviera autonomía respecto a otras autoridades y que se revisara la actuación de su Consejo General por sus omisiones en la regulación de las campañas electorales (documento de la reunión de consejeros locales y distritales del IFE, Jalisco, mimeo.). Hubo una contradicción entre la composición del Consejo General del IFE y la conformación del consejo local y de una gran parte de los consejeros distritales. Una antigua funcionaria del IFE, Clara Jusidman, apunta: "Desde la forma como se eligió a los actuales consejeros electorales con el acuerdo de sólo dos fuerzas políticas, hasta las intervenciones interesadas de Elba Esther Gordillo, del SNTE, en la estructura y organización del Instituto Federal Electoral, experimentamos un retroceso en algo que muchos sentíamos concluido: el tener proceso y autoridades electorales confiables, transparentes y eficaces [...]. El Consejo General del IFE inició con una duda razonable sobre su ilegitimidad e imparcialidad, y a medida que fueron dándose las actividades del proceso, esta duda pasó de razonable a justificada [...]. Varias organizaciones [...] en todo el país tuvimos que promover el registro de candidatos ciudadanos para la conformación de consejos locales [...]. Fue necesario convencer en todo el país a ciudadanos con experiencia previa como consejeros para que aceptaran volver a tomar las posiciones, pues muchos estaban muy escépticos de la calidad del proceso que se podría lograr dado el bajo perfil del Consejo General [...]. Con las decisiones sesgadas de los consejeros electorales del Consejo General, las intervenciones que pudieron haber realizado [...] los consejeros ciudadanos de origen ciudadano para abrir los paquetes en los que se encontraban inconsistencias en las actas o alteraciones en los paquetes y que hubieran permitido tener mayor certeza sobre los resultados desde el conteo distrital fueron bloqueadas por instrucciones de consejeros electorales que personalmente estuvieron llamando a los presidentes de los consejos distritales, en alianza con los representantes del PAN en los distritos" (Jusidman, 2006: 6-8). sidente del IFE visitó Guadalajara para presentar lo que se denominó El libro blanco de la elección federal de 2006. Se trataba de seis folletos de propaganda del organismo electoral con motivo de la organización del proceso, la jornada electoral, las encuestas y los resultados electorales ${ }^{35}$. Aunque reconocía algunos errores, insistía en que éstos no habían influido en los resultados. Fue cuestionado sobre el hecho de que, siendo la diferencia entre los dos punteros tan estrecha, cómo podía afirmar que los errores del IFE no habían incidido en el resultado. Algunos asistentes al evento de la presentación dijeron que se trataba de los cuadernos negros del fraude. Un dirigente de un movimiento democrático le dijo al presentador:

Usted es corresponsable del fraude que sufrimos [...]. Usted llegó al IFE como consecuencia de una negociación entre el PRI y el PAN, impulsado particularmente por Elba Esther Gordillo. Se conocen sus vínculos con la familia Zavala, particularmente con el propio Felipe Calderón. Con estos antecedentes, evidentemente usted no es garantía de imparcialidad [...]. Hay que decir que el IFE se hizo de la vista gorda, consintió y actuó como cómplice de las violaciones que se cometieron a nuestra Carta Magna y a la misma ley electoral.

Varios de los asistentes exigieron que renunciara ${ }^{36}$. La intromisión descarada del presidente en la campaña electoral presidencial creó un ambiente fraudulento. En una entrevista del Grupo Imagen a su regreso de Montevideo, Vicente Fox se ufanó de que le había tocado ganar dos veces: en el año 2000 y el 2 de julio de 2006. Comentando esto, el ex consejero ciudadano Miguel Ángel Granados Chapa escribió: "En el contexto de su grosera intromisión en el proceso electoral, reconocida aun por el Tribunal Electoral del Poder Judicial de la Federación, su campanudo autorregodeo es una inequívoca confesión de parte"37.

\footnotetext{
${ }^{35}$ El editorial del periódico El Universal del 30 de enero de 2007 tituló su comentario "IFE, memoria incompleta". Hacía ver que las cifras que daban "los cuadernillos" del IFE sobre el gasto de los partidos en medios electrónicos era 50\% inferior a las que una empresa especializada había cuantificado. Ese periódico señaló que a los cuestionamientos que se le habían hecho al IFE ahora se añadía la falta de rigor en la transparencia.

${ }^{36}$ Entrevista con participantes en el diálogo que sostuvo en el periódico Público y con varias personas que escucharon una entrevista radiofónica. Reportes de la presentación aparecidos en los periódicos $L a$ Jornada y Mural, 20 de enero de 2007.

${ }^{37}$ Miguel Ángel Granados Chapa, "Intereses partidistas", Reforma, 9 de
} 


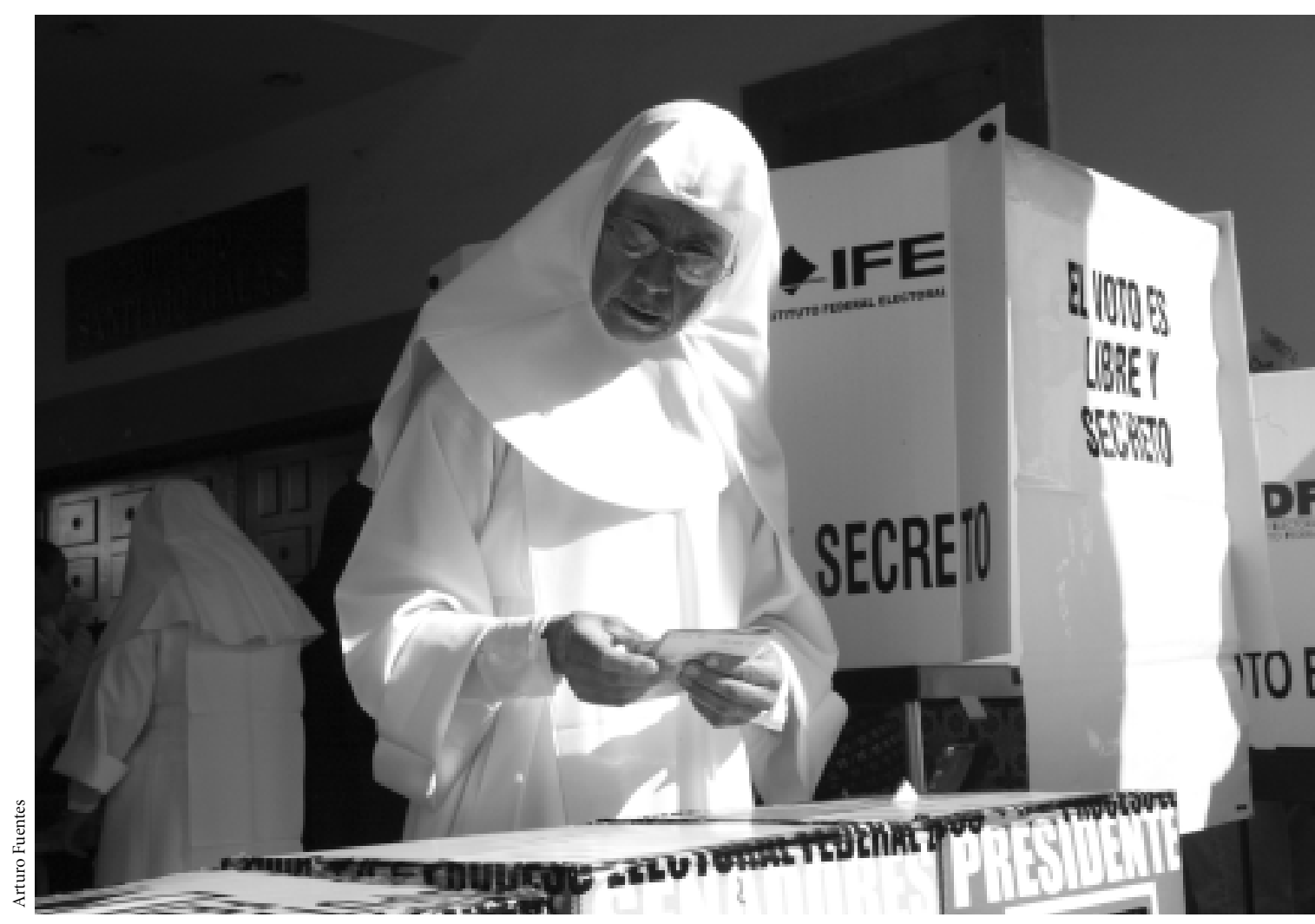

Proceso electoral de 2006.

\section{EL RECUENTO DE VOTOS DE LA ELECCIÓN PRESIDENCIAL}

La demanda del recuento total de votos no prosperó. El Tribunal sólo aceptó que se hiciera en 9\% de las casillas. No obstante, Jalisco fue la entidad en donde más casillas fueron recontadas: 2705 , equivalentes a $23 \%$ del total de casillas recontadas y a $33.4 \%$ de las correspondientes a Jalisco $^{38}$. Se revisaron 2705 en 17 de los 19 distritos. En

noviembre de 2006. Posteriormente, este mismo articulista, que fue uno de los primeros consejeros ciudadanos del IFE, puntualizó: "El proceso electoral se enturbió en varias de sus porciones, y aquí y allá aparecieron irregularidades, amén de los abusos orquestados del presidente de la República, la cúpula empresarial y el IFE; y el Tribunal Electoral [...] ni como instancia constitucional de calificación actuó con vigor y transparencia, y así, en vez de producir certezas, causó incertidumbre" (Reforma, 20 de noviembre de 2006).

${ }^{38}$ Hay que recordar que, pese a tantas irregularidades, en los cómputos el distrito de Tlaquepaque se recontó 73\% de las casillas, en el de Tonalá, 61\%; en el de Jocotepec, 58.6\%; en el VI de Zapopan, 60.9\%; y en el de Tepatitlán, 56\%. Hay que tener en cuenta que en las elecciones locales de $1995 \mathrm{hu}$ bo inconsistencia en $40 \%$ de las casillas jaliscienses. En las elecciones federales de 2000 las inconsistencias se presentaron en $38.1 \%$ de las casillas, mientras que en 2006 el porcentaje se elevó a $52.8 \%$. El distrito con mayores inconsistencias fue el distrito correspondiente a Tlajomulco, con $78.7 \%$; le seguió el de Tlaquepaque, con $74.4 \%$. El VI de de Zapopan tuvo 68.2\%, y el X, también de Zapopan, alcanzó $65.5 \% 39$. Se adujo la baja escolaridad para explicar las inconsistencias, pero la mayoría de estos

distritales en Jalisco, según los datos oficiales del IFE, sólo fueron abiertos 130 paquetes, $4.5 \%$ de los paquetes abiertos a nivel federal ese día. ${ }^{39}$ Rubén Alonso, Estudio de inconsistencias en las casillas, mimeo. 
distritos se encuentra en la zona metropolitana, pues en los distritos rurales las inconsistencias fueron menores. El vocal ejecutivo del distrito de Lagos de Moreno reportó:

[...] en este distrito electoral se registraron 206 casillas con error aritmético, de las cuales en 166 sólo se registra el error con un voto de diferencia, que independientemente de la explicación a la razón de este error, evidentemente no causa agravio a los partidos que quedaron en segundo y tercer lugar, cuya diferencia de votos obtenidos con respecto al primer lugar es infinitamente menor a la cifra observada como error aritmético.

Consideró que las inconsistencias no eran determinantes para el resultado de la elección. También afirmó:

El hecho de que existan diferencias o discordancia entre el número total de votos y boletas inutilizadas con el número de boletas recibidas, encuentra explicación en el hecho de que en algunos casos los ciudadanos se llevaron su boleta o la depositaron en otra urna, ya sea de la elección local o federal, distinta a la correspondiente a su casilla; pues [...] mientras en unas casillas sobran boletas en otras faltan, es el caso de casillas básicas con respecto a sus contiguas o viceversa, las que se ubicaron el día de la jornada electoral

No obstante, lo que argumentaron los perredistas era precisamente que se había dado un robo hormiga, y que bastaba la alteración de muy pocas boletas para que en el conjunto se estableciera la diferencia entre Calderón y López Obrador. Llamó la atención que en el tercer distrito con cabecera en Tepatitlán las elecciones por el candidato presidencial panista hubieran rebasado $60 \%$ de votación. Mientras las diferencias entre las votaciones panistas por presidente de la República y por gobernador en la mayoría de los distritos oscilaban entre punto y medio y dos puntos y medio, en el caso de los distritos alteños esta diferencia se duplicó en el de Lagos, y hasta se triplicó en el de Tepatitlán. Eso mismo levantó sospechas ${ }^{41}$.

No obstante, no hubo recuento en todos los casos en

\footnotetext{
${ }^{40}$ Nota informativa enviada al vocal ejecutivo de la Junta Local de Jalisco el 21 de agosto de 2006.

${ }^{41}$ Así, en el distrito XIX hubo un punto y medio más en la elección por Calderón que en la de Emilio González; en el primer distrito la diferencia fue de 1.8; en el XVIII de 1.9; en el XV de 2.6. Sin embargo, en el distrito II la diferencia alcanzó 4.3, y en el III llegó a 6.7.
}

los que se denunciaron graves errores. Por ejemplo, el periódico Público demostró que en la casilla 769 básica del distrito XIV se habían contabilizado 555 votos para presidente, cuando hubo 455 votos para cada una de las otras elecciones (senadores, diputados federales, gobernador y munícipes). Se entrevistó a quien estuvo al frente de esa casilla, quien reconoció que se le habían dado cien votos de más a Calderón. Esa casilla no fue recontada y el error no fue corregido ${ }^{42}$.

La Coalición por el Bien de Todos pidió que en Jalisco se recontaran 4263 casillas. Argumentó que 62\% de las casillas tenía irregularidades y que estaban en duda $35 \mathrm{mil}$ votos. Lo primero con lo que se toparon consejeros distritales pertenecientes a movimientos ciudadanos independientes fue que algunos magistrados designados por el TEPJF para encabezar los recuentos eran militantes panistas, como el magistrado que estuvo en el distrito VIII, o no tenían conocimientos en materia electoral, como en el distrito XIII. Hubo quejas de que en el distrito III, con cabecera en Tepatitlán, el magistrado apoyaba descaradamente los alegatos del PAN, cosa que también sucedía en otros distritos. La tónica general que encontraron fue la resistencia de los magistrados para poner en las actas incidencias que revelaran manipulación. La desconfianza que suscitó la actuación del personal del Tribunal en varios consejeros repercutió en que se les dificultara ir al sanitario o a buscar algo para comer, porque temían que se aprovecharan esos momentos para torcer el proceso. Otro hecho que desconcertó a estos consejeros fue que, en una alta proporción, los paquetes de los votos válidos estaban abiertos, no así los de los votos nulos. Ante este señalamiento, personal del IFE adujo que se habían tenido que abrir para enviar material al Tribunal, pero en el Tribunal esto fue desmentido ${ }^{43}$. No encontraron en los paquetes

\footnotetext{
42 Público, 13 de julio de 2006. Habría que recordar que en el cómputo debieron haberse abierto los paquetes cuyas actas registraban inconsistencias, pero esto sólo se hizo en 5\% de lo que legalmente debió revisarse. De un examen de las actas divulgadas por el IFE en su página de Internet, José Antonio Crespo destaca que, por ejemplo, en el "distrito XV de Jalisco no se abrió ni un solo paquete de los más de 150 cuyas actas mostraban inconsistencias, en muchos casos nada pequeñas: una registraba 322 boletas inconsistentes, otras 117, 106, 93, 83, 70, y así sucesivamente" (José Antonio Crespo, "Las actas del IFE", Excélsior, 29 de enero de 2007).

${ }^{43}$ El 11 de julio de 2006 el presidente del IFE giró un oficio en el que
} 
el listado nominal con el que se hubiera podido cotejar si el número de votos correspondía a los votantes. En el recuento se demostró que en pocos casos los números cuadraban. En la mayoría había votos faltantes o sobrantes en relación con lo que estipulaban las actas. En el distrito VIII se dieron casos en que sobraban 130, 25, 4, 3, o faltaban $18,13,5 \ldots$ Hubo casillas en las cuales votos legítimamente marcados a favor de López Obrador posteriormente habían sido cancelados con dos rayas cruzadas por la misma mano ${ }^{44}$.

La prensa también dio cuenta de irregularidades. Se detectaron casos en los que había el mismo número de votos por el candidato panista tanto en la casilla básica como en la contigua. Hubo casillas en las que se aumentaron los votos de Calderón y otras en las que se le disminuyeron a López Obrador ${ }^{45}$. Mientras el PAN reconocía que había errores mínimos en 59\% de las casillas, el PRD aducía que había una recuperación para López Obrador de voto y medio en promedio por casilla. Preocupaba que la tendencia fuera que había votos de más para Calderón y votos de menos para López Obrador. El PRD denunció que en Jalisco hubo 18830 votos alterados, y que en 1252 casillas hubo boletas de más y 357 boletas de menos. Las cifras oficiales habían señalado que Calderón tuvo 1435334 votos en Jalisco. El Tribunal anunció que había anulado 64 casillas. Por juicios de inconformidad, el PAN perdió 8569 votos, y debido a ajustes en el recuento, 451. El cómputo modificado asignaba al candidato panista 1426 237. En el caso de la Coalición por el Bien de Todos, por la anulación de las 64 casillas perdió 4703 votos y ganó en el recuento 558, con lo que su cifra recompuesta fue de 555239 (la cifra oficial le había reconocido 559 266). La Alianza por México perdió en la anula-

autorizaba a los consejos distritales la apertura de los paquetes electorales. Esto fue denunciado por el PRD. El organismo electoral respondió que lo había hecho a petición del tribunal, pero éste lo desmintió. El 14 de noviembre de 2006 un senador perredista demandó la renuncia de los integrantes del Consejo General del IFE; entre las argumentaciones aducidas se encontraba la apertura ilegal de los paquetes electorales, <www.senado.gob.mx >.

${ }^{44}$ Entrevistas a consejeros distritales, 24 de agosto de 2006 y 18 de octubre de 2006. Testimonio público de consejeras del distrito XIX en el informe anual del Instituto Mexicano para el Desarrollo Comunitario (IMDEC), 8 de noviembre de 2006.

45 Público y Mural, 5, 6, 7, 8, 9, 10 de agosto de 2006. ción 7230 y en el recuento 138. No obstante, el Tribunal nunca transparentó la información de cuáles habían sido las casillas anuladas ${ }^{46}$.

\section{LOS PARTIDOS ANTE LA ELECCIÓN DE GOBERNADOR}

Antes de que se pronunciara el organismo electoral, la noche de la jornada electoral el gobernador dio un mensaje televisado para anunciar el triunfo del panista Emilio González. El 9 de julio el Instituto Electoral del Estado de Jalisco le dio la constancia de mayoría al candidato del PAN. El candidato prísta culpó de su derrota al voto del miedo y se quejó de la inequidad. Se defendió diciendo que todas las acusaciones que se le habían hecho eran mentira ${ }^{47}$. Pero no quiso impugnar el proceso. Se especuló que había llegado a una negociación con el gobierno panista para que no lo siguieran asediando con el caso del fraude en el IMSS y dejaran de ligarlo a narcotraficantes. Por su parte, altos directivos panistas alegaron que en la campaña sólo habían planteado lo que se decía en la prensa, pero que ya olvidaban sus acusaciones contra Zamora. Alabaron como madura la posición de Zamora por anteponer los intereses del estado a los de su partido ${ }^{48}$. Entre los príístas se pensó que lo que había pesado no era lo aducido públicamente de contribuir a salvaguardar la paz social y la estabilidad de Jalisco, sino una negociación para que lo dejaran en paz. Pero no estaban de acuerdo en que se legitimara una elección en la cual se había violentado en todo tiempo y en todo momento el estado de derecho, una elección que se había caracterizado por utilizar dependencias públicas como herramienta para hacer campaña electoral. Además, el argumento era falaz, porque sería legal acudir a los tribunales y era precisamente uno de los caminos para contribuir a la no desestabili-

\footnotetext{
${ }^{46}$ Entrevista con el vocal ejecutivo del IFE en Jalisco, 8 de noviembre de 2006.

${ }^{47}$ Mural, 13 de julio de 2006.

${ }^{48}$ Mural, 6 de julio de 2006. En la defensa que hizo el PaN de su victoria ante el tribunal electoral de Jalisco alabó al candidato priísta porque de forma "responsable y caballeresca" había reconocido el triunfo del PAN.
} 


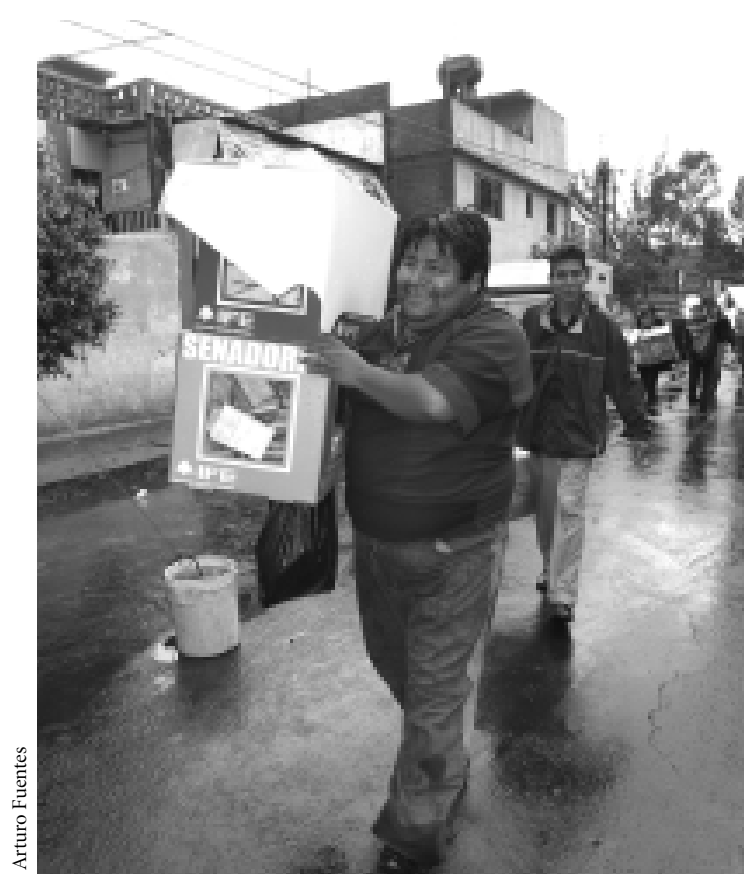

Proceso electoral de 2006

zación. En el PRI también hubo una autocrítica. Se aceptó que en el equipo de campaña de Zamora hubo una gran actitud de soberbia y que se minimizó al contrincante panista ${ }^{49}$. La imposición de candidatos influyó en el conjunto de la campaña. Además, su candidato presidencial era mal visto y les restaba adhesiones.

Los panistas, por su parte, evaluaron que la versión acerca de que Zamora era bien visto por el gobernador protegió al gobierno para que la campaña priísta no atacara a la gestión panista. Reconocieron que la guerra sucia a nivel nacional había impactado y que muchos habían salido a votar no precisamente a favor del PAN sino en contra de López Obrador y de su partido. En el caso de la campaña por el gobierno del estado, aceptaron que la guerra sucia en contra de Zamora había sido fundamental; no obstante, precisaron que se trataba de un candidato vulnerable porque tenía un historial problemático ${ }^{50}$.

\footnotetext{
${ }^{49}$ Entrevista con Jesús Reynoso, 22 de octubre de 2006.

50 Entrevista con Alonso Ulloa, 22 de septiembre de 2006.
}

El candidato a gobernador de la Coalición por el Bien de Todos destacó que la campaña de López Obrador había permitido crecer electoralmente al PRD. En sus recorridos por Jalisco atraía gente. Hubo personas que aunque traían propaganda de Zamora, se le acercaban para decirle que votarían por él. Criticó que tanto Emilio González, con su campaña "Mira", como Arturo Zamora, con su campaña "Ciudad Real", hubieran gastado cada uno alrededor de 200 millones de pesos de sus respectivos municipios. Resaltó que era inmoral e ilegal hacer gastos de imagen cuando había tantas otras necesidades. Ibarra precisó que, cuando dejó el PRI, muchos jóvenes se fueron con él a su campaña y que se habían dado varios desplazamientos silenciosos en los municipios. Consideró que la derrota de Zamora se debió a que en el PRI hubo fracturas fatales. Pese a los recursos de muchos gobernadores, el proceso interno tuvo serios problemas. Una derrota que debía valorarse como muy costosa era que no pudieron mantener el triunfo en 63 municipios, pues las reformas constitucionales necesitan el aval de dos terceras partes de los municipios. Al bajar el número de municipios se perdió esa barrera. En cambio, percibió que el proceso electoral había dejado a un panismo ensoberbecido y arrogante ${ }^{51}$.

El candidato de la Coalición por el Bien de Todos (PRDPT) denunció que el gobierno del estado se había puesto al servicio de la campaña del PAN, que habían sido utilizados partidistamente programas sociales, obra pública, reparto de materiales, etc. El gobernador le dio un tinte electoral a sus giras, promocionales y entrega de obras. Se había dado, por tanto, una elección de Estado. Para dejar precedente, el 8 de agosto de 2006 impugnó la elección a gobernador ante el Tribunal Electoral del Poder Judicial del Estado de Jalisco. En esa impugnación argumentó que se habían violado los principios constitucionales y legales de equidad, legalidad, certeza, independencia e imparcialidad:

Tanto el Partido Acción Nacional y sus candidatos a diputados locales y gobernador, así como el Partido Nueva Alianza [...] participaron en lo que públicamente se conoció co-

${ }^{51}$ Entrevista con Enrique Ibarra, 21 de octubre de 2006. 
mo "campañas de lodo" o "guerra sucia", consistentes en la difusión de propaganda electoral de manera sistemática, deliberada y permanente de diversos spots o anuncios pagados en medios de comunicación electrónicos como radio y televisión, así como en prensa escrita, con contenidos violatorios a lo que la ley permite para la propaganda electoral, mediante expresiones verbales o alusiones ofensivas a las personas, candidatos y partidos políticos contendientes en la elección a gobernador durante el proceso electoral, coaccionando a los ciudadanos en el ejercicio de su libertad de sufragio por medio del temor o miedo, la duda o la sospecha, en beneficio del candidato del PAN y en perjuicio de algún candidato a gobernador del estado de Jalisco, con intención de provocar en el ánimo de los electores un rechazo en contra de los partidos políticos o candidatos afectados; actos que se realizaron de manera continuada desde el día $1^{\circ}$ de abril de 2006 hasta el 29 de junio del mismo año, en prácticamente la totalidad de la frecuencia de radio de Amplitud Modulada y de Frecuencia Modulada con cobertura en el estado de Jalisco, transmitiendo un promedio de 30 impactos o spots publicitarios por hora, de una duración promedio de entre 20 y 30 segundos cada uno, todos con los mencionados contenidos contrarios a la Constitución y la ley; lo mismo se transmitió por televisión con promedio de diez impactos por hora con duración promedio de entre 20 y 30 segundos cada uno, por los canales transmitidos por las empresas televisoras Televisa, en sus cuatro canales de señal abierta, y TV Azteca en sus dos canales de señal abierta de cobertura en los 125 municipios del estado de Jalisco, y a través de los diversos canales de los sistemas de cable de las empresas Megacable y Telecable de Zapopan, ambas empresas con cobertura en los cuatro municipios metropolitanos de Guadalajara, Zapopan, Tlaquepaque y Tonalá, así como en por lo menos 25 ciudades más del estado; más grave aún es que los partidos Acción Nacional y Nueva Alianza destinaron para fines contrarios a la Constitución y a la ley recursos provenientes del financiamiento público y privado para las actividades tendientes a la obtención del voto ${ }^{52}$.

La impugnación subrayaba que la guerra sucia a nivel federal había afectado a la Coalición por el Bien de Todos en el ámbito local. También debía contemplarse la campaña monumental desplegada por el Poder Ejecutivo Federal a través de spots en televisión. Dicha campaña, que había competido con la de los partidos políticos, había hecho referencia velada y expresa a favor del partido en

52 Coalición por el Bien de Todos, Impugnación de la elección de gobernador del Estado de Jalisco, 2006, <www.triejal.gob.mx> . el gobierno. Los medios de comunicación habían reportado monitoreos que comprobaban la transmisión de medio millón de spots con un costo aproximado de 1709 millones de pesos. La magnitud de esta campaña tuvo efectos en el ámbito de la elección local. Además, el PAN había combinado las candidaturas del ámbito local y del federal. Todo esto atentaba contra la equidad. Se aducía también la campaña que emprendieron algunos organismos como el Consejo Coordinador Empresarial, en la que se exaltó la opción de la continuidad y se desalentó la opción del cambio.

En un punto central se colocaron los actos de difamaciones por medio de la Procuraduría General de la República (PGR), que había ordenado y publicitado el aseguramiento de bienes del candidato prísta por presuntas conductas constitutivas de delitos del orden penal tres días antes de la jornada electoral. La PGR había actuado de manera facciosa y dolosa para sembrar entre los ciudadanos clima de confusión, incertidumbre y miedo. Además, el proceso electoral había sido inequitativo, pues se habían destinado recursos para una campaña electoral prohibida.

Otra línea para impugnar se basaba en que servidores públicos de todos los niveles habían intervenido en la campaña con declaraciones públicas. Se argumentaba que el PAN había violado el tope de gastos de campaña. Se aducía la información del organismo electoral según la cual, faltando todavía un mes de campaña en lo concerniente solamente a televisión, radio, prensa y anuncios panorámicos en la zona metropolitana de Guadalajara, la campaña a gobernador por parte del PAN había gastado 25.1 millones de pesos. Teniendo en cuenta que ese monitoreo no contemplaba otro tipo de erogaciones como gasto corriente, operación política, viáticos, telefonía fija, telefonía celular, alimentos, elaboración y colocación de gallardetes y pendones, elaboración y colocación de mantas, pintas de bardas y demás gastos que se generan en el desarrollo de las campañas electorales; $y$ viendo que en ese mismo reporte a la Coalición se le anotaba un gasto de 4.4 millones de pesos cuando en realidad habían gastado 8.8, se llegaba a la conclusión de que los monitoreos sólo contemplaban 50\% de los gastos. Esto llevaba a la conclusión de que si se examinaban los gastos reales de 
la campaña panista, ésta había rebasado con mucho los topes legales. La impugnación llamaba la atención sobre otro tipo de gastos, de los cuales no tenía certeza de que se hubieran reportado a la autoridad electoral. Se refería en particular a los elevados honorarios del asesor extranjero de nombre Joaquín Pérez Rodríguez, nacido en $\mathrm{Cu}-$ ba y de nacionalidad venezolana, pues las autoridades de la campaña del PAN habían aceptado la participación de este individuo en su campaña. Se atribuía a ese sujeto el diseño de las estrategias de comunicación de la guerra sucia. Por labores similares había cobrado más de 1.5 millones de pesos. Haciendo una revisión puntual de la campaña por gobernador del PAN se llegaba a la conclusión de que había rebasado los 100 millones de pesos. No había que dejar de lado que la intromisión de un extranjero en asuntos políticos constituía una violación a la Constitución.

Se ofrecieron pruebas de que el gobernador Ramírez Acuña había desplegado una estrategia de comunicación que también había competido con la de los partidos políticos. Éstos, a excepción del PAN, que era el beneficiario, habían quedado en situación de desventaja frente al potencial de gasto realizado por el Ejecutivo. El poder ejecutivo del estado había asesorado y apoyado a los candidatos panistas en forma deliberada, desviando recursos públicos y aprovechándose de la situación privilegiada de ser gobierno en la entidad, en horarios laborales, en instalaciones públicas, y entregando información de primera mano. La prueba de esto se encontraba en las declaraciones del coordinador general de la campaña del PAN, que había dado a conocer la existencia de reuniones de esa naturaleza. El gobierno estatal había desplegado una campaña clientelista. Entre los ejemplos de eso estaba el reparto de lotes de tinacos de agua en beneficio de candidatos panistas. Hubo ilegalidad e inequidad. Todo esto había atentado contra la libertad del sufragio. Además, el candidato panista había empleado en muchas ocasiones elementos religiosos en su campaña, lo cual era ilegal. La impugnación acusó al organismo electoral de haber sido omiso y de haber consentido ilegalmente los actos inconstitucionales, así como de romper con los principios de la democracia. Se condujo con parcialidad, inequidad e ilegalidad, dado que al haber conocido en tiem- po y forma los hechos públicos que se impugnan, fue omiso, permitió la propaganda electoral y los actos de campaña inconstitucionales, así como la intervención de las autoridades. La impugnación concluye que procede "la nulidad de elección de tipo abstracto" por la violación de los principios electorales fundamentales ${ }^{53}$.

\section{LOS FALLOS DE LOS TRIBUNALES}

Los partidos llevaron a los tribunales electorales casos de algunos distritos y municipios. El PRI impugnó incluso municipios que habían ganado para tratar de compensar los alegatos de sus contrincantes. El Tribunal Electoral del Poder Judicial de la Federación se atuvo a una causal genérica para revertir la elección en dos municipios. En Villa Purificación, porque un director de obras municipales había sido representante del PAN, anuló esa casilla. Esto hizo que perdiera ese municipio y pasara al PRI. En Bolaños, porque el director de obras municipales fue funcionario de casilla, se anuló la casilla y pasó a manos del PAN. Posteriormente, el Tribunal Electoral del Poder Judicial del Estado anuló una casilla en la elección municipal de Atenguillo porque cuatro ciudadanos habían sufragado sin estar en el listado nominal. Con esto, el triunfo pasó del PRI al PAN. Debido a estos cambios, el PAN se quedó con 64 municipios y el PRI bajó a 45. El tribunal federal confirmó el empate en la elección municipal de Tuxcueca. El Congreso de Jalisco nombró un concejo municipal y convocó a nuevas elecciones para el 18 de febrero de 2007. En esa fecha ganó el PAN, con lo que aumentó un municipio a su cuenta ${ }^{54}$. También el Tribunal federal confirmó que el Partido Verde debía tener un diputado.

El fallo del TEPJF en la elección presidencial fue dura-

\footnotetext{
${ }^{53}$ Ibidem.

${ }^{54}$ Cinco días antes de las nuevas elecciones en el municipio de Tuxcueca, el candidato panista denunció la compra de votos por parte del PRI. Finalmente, la ventaja que tuvo el panista fue de 281 votos sobre su rival priísta. El presidente estatal del tricolor anunció que impugnaría los resultados aduciendo que se habían dado acarreos de votantes en vehículos oficiales. Con ese triunfo, el panismo consolidó la ventaja que significaba tener más de la mitad de los municipios, pues para cambios constitucionales se necesitaba contar con la aprobación de esa proporción de municipios.
} 
mente criticado ${ }^{55}$. La resolución del Tribunal Electoral del Poder Judicial del Estado de Jalisco en el caso de la elección de gobernador fue una burda copia. Alegó que no se podía aplicar la nulidad abstracta porque no se habían presentado violaciones sustanciales. Argumentó que le habían llevado como pruebas "indiciales" recortes periodísticos. Eso bastaba para que el tribunal hubiera realizado su propia investigación, pero no la hizo. La dirección de la campaña en manos de un extranjero se justificó diciendo que nada malo tenía una asesoría. Uno de los magistrados reconoció que se habían dado irregularidades, pero que no habían sido "determinantes" para el resultado ${ }^{56}$. El PRD acusó al Tribunal estatal de actuar con parcialidad por haber desechado pruebas relevantes, e interpuso un juicio de inconstitucionalidad ante el Tribunal Electoral Federal para que clarificara si el Tribunal Electoral Estatal había actuado apegado a la ley. El 30 de enero de 2007 el Tribunal Electoral del Poder Judicial de la Federación desechó la impugnación perredista. El PRD señaló que había fallas en el diseño jurídico, pues los alegatos que había esgrimido respecto al exceso de gasto no fueron atendidos porque faltaba que la autoridad administrativa se hubiera pronunciado sobre la fiscalización, cosa que pasaría muchos meses después. Las elecciones quedaron bajo sospecha.

${ }^{55}$ El ex consejero electoral Jaime Cárdenas demostró que ese fallo había sido un sinsentido jurídico en un escrito titulado Once absurdos jurídicos sobre el Tribunal Electoral (mimeo).

${ }^{56}$ Los argumentos del tribunal los pormenorizó el periódico Público el 1 de diciembre de 2006, y se pueden consultar en <www.triejal.gob. $\mathrm{mx}>$. La resolución del Tribunal Electoral del Poder Judicial del Estado de Jalisco del 30 de noviembre de 2006 consta de 600 páginas. Contiene múltiples errores ortográficos, de puntuación y de sintaxis. Mientras que el PRD alegó, apelando a tesis de jurisprudencia emitidas por la Sala Superior del Tribunal Electoral, que las notas periodísticas sí tenían valor probatorio, el PAN, en su defensa, insistió en que carecían de eficacia porque eran producto de la mercadotecnia (p. 107). En lo relativo a la guerra sucia, el Tribunal estatal respondió que los argumentos ofrecidos no demostraban que la propaganda hubiera producido temor o animadversión colectiva que afectara la libertad de los ciudadanos (p. 376). Dicho Tribunal recalca: "No existen condiciones que permitan establecer de manera objetiva que la intención del voto en la pasada jornada electoral fue afectada de manera preponderante por la difusión de propaganda y spots negativos" (p. 378). A las notas periodísticas las considera sólo como "leves indicios". En relación con el asesor extranjero dijo que esas asesorías no implican "inmiscuirse en asuntos políticos del país” (p. 466). En el punto relativo a los topes de campaña el Tribunal adujo que el organismo electoral todavía no había hecho el estudio correspondiente.

\section{EL CAOS DEMOCRÁTICO}

Las elecciones jaliscienses estuvieron sobredeterminadas por las campañas nacionales $\mathrm{y}$, a su vez, potenciaron los resultados generales. No obstante, el gasto excesivo en medios en el que intervino indebidamente el mismo presidente Fox (como fue reconocido incluso por el Tribunal Federal) sólo logró que dos de cada diez ciudadanos inscritos en la lista nominal votaran por el candidato panista a la presidencia, Felipe Calderón, pues cuatro no fueron a las urnas, y otros cuatro lo hicieron por otras opciones. En Jalisco, tres de cada diez ciudadanos inscritos en la lista nominal lo hicieron por Calderón, y eso influyó en el resultado. Hubo una buena proporción de voto cambiante. El PAN se benefició de alrededor de 10\% de votos de otros partidos. Si uno de cada diez que votó por Calderón ya no lo hizo por el candidato panista a la gubernatura, cuatro de cada diez que sufragaron por $\mathrm{Za}-$ mora, candidato a gobernador del PRI, no avalaron a su candidato presidencial. En el caso de la Coalición por el Bien de Todos, seis de cada diez que apoyaron a López Obrador no quisieron votar por el candidato a gobernador de esa coalición. López Obrador recogió el voto de muchos priístas, pero también hubo prístas que impulsaron a Calderón. Este último contó con el apoyo de los maestros de Nueva Alianza, que antes eran votos cautivos priístas. La campaña lopezobradorista propició el crecimiento del voto de la izquierda por legisladores federales y locales ${ }^{57}$.

El PRD recuperó el tercer sitio que había perdido en los comicios locales anteriores. No obstante, debido a que la cúpula del PRD en Jalisco apostó en lo local por la candidatura priísta al gobierno de la entidad, este doble juego repercutió en que el crecimiento de las votaciones por diputados de ese partido no alcanzara los niveles que había obtenido en los comicios de 199758 . La candidatura presidencial panista fortaleció la candidatura a la gubernatura de ese partido. Por su parte, la derrota del candi-

\footnotetext{
${ }^{57}$ Aunque una elevada proporción del voto por López Obrador no implicó que los que así votaron se hubieran pasado a su partido, sino que muchos priístas lo preferían a su candidato presidencial.

${ }^{58}$ Había un doble mensaje que propiciaba confusión entre los votantes.
} 
dato del PRI al gobierno de Jalisco se debió tanto a la guerra sucia como a las divisiones internas de ese partido, a las exclusiones de cuadros con influencia electoral, a la soberbia de su equipo de campaña y a la excesiva confianza que pusieron en las encuestas electorales ${ }^{59}$. En la elección del gobernador, $27.5 \%$ de los ciudadanos de las listas electorales votaron por el PAN y 25.2\% por el PRI; la opción perredista estuvo por debajo de 5\%. Pese a que las elecciones municipales hay que leerlas desde la contienda de los grupos locales, también hay una traducción para los partidos. De los inscritos en las listas nominales del registro electoral, $26 \%$ hizo triunfar al PAN, 22\% fueron al PRI y $6 \%$ al PRD. Esto muestra que pervive la tendencia hacia el bipartidismo ${ }^{60}$.

Calderón ganó gracias al voto del miedo ${ }^{61}$, pero también a una alianza de hecho que le atrajo el voto corporativo y autoritario del partido del sindicato de maestros. También se dinamizó con recursos públicos y con nuevos clientelismos. Más que una opción por un personaje determinado, operó el repudio a otra candidatura fuerte. La vulnerabilidad del candidato prísta a la gubernatura más la sobredeterminación de la elección federal influyó para que no se diera en Jalisco el voto de castigo al mal gobierno de Ramírez Acuña ${ }^{62}$. Después de la elec-

\footnotetext{
${ }^{59}$ Las encuestas de María de las Heras, difundidas por Público, fueron las únicas que tradujeron sus puntos en número de votos. Mientras que el candidato panista tuvo $8 \%$ menos de los votos estimados, Zamora estuvo debajo en $20 \%$

${ }^{60}$ Conviene no olvidar que el ambiente fraudulento influyó directamente en la elección presidencial, pero que repercutió también en las otras cinco elecciones que tuvieron lugar en Jalisco en la misma fecha. ${ }^{61}$ En la historia electoral reciente la propaganda política instigadora del miedo ha tenido abundantes cosechas de votos. Con la descomposición política de 1994 el régimen echó mano del voto del miedo. Ante los escenarios desastrosos que se pintaban en los medios electrónicos, la mayoría de los votantes temió cualquier opción de cambio. Sin embargo, seis años después, la oferta de un cambio fue la que empujó a los votantes a sacar al PRI de la presidencia de la República. De nueva cuenta, en 2006 el cambio fue pintado con tonos apocalípticos y el temor al riesgo operó, pero ya no tan contundentemente como doce años antes pues, pese a las manipulaciones, hubo prácticamente una proporción similar la que refrendaba la continuidad que la que apostaba al cambio. En el año 2000 hubo una euforia popular por el cambio. En 2006 se ha mantenido una contundente protesta por los ilícitos métodos para impedir el cambio.

62 Andrés Valdez señaló que sería equívoco plantear que la copiosa votación panista en Jalisco se hubiera dado para refrendar al gobierno local, pues abundaban los problemas: inseguridad pública, pobreza,
}

ción el panismo lanzó el mensaje de la impunidad. No importaban las acusaciones contra Zamora, ya no se investigarían porque no impugnaba la elección. También sería un error querer atribuir la consolidación electoral jalisciense al predominio del conservadurismo. Hay núcleos conservadores influyentes, pero han crecido las manifestaciones que se han sacudido ese conservadurismo (Cortés, 2005). No obstante, sí se manifestó la consolidación de lo que Boaventura de Sousa llama el fascismo societal ${ }^{63}$ y la emergencia de un fascismo paraestatal (Santos, 2005). Entre ambos hay un reforzamiento, pues los poderes fácticos medran en el fascismo societal y lo refuerzan.

Se dieron unas elecciones muy competidas, pero no desarrolladas limpiamente. No fueron equitativas y la campaña sucia instigó no sólo un voto del miedo, sino del odio. Se hicieron intervenir con fuerza factores de una poderosa violencia simbólica. Se alimentó la intolerancia, que es destructora de la democracia. Hubo una desmedida campaña mediática pagada por la presidencia de la República a favor del candidato panista y adversa a sus contrincantes. Además del impacto nacional en lo local, en Jalisco hubo un remedo de la tónica de esa campaña ${ }^{64}$. Los grandes medios de comunicación han concentrado tanto poder que producen un individuo que se somete, y se han convertido en los grandes electores (Mattelart, 2006). Se fraguó un ambiente fraudulento que atentó en

abusos, arbitrariedades, excesos y autoritarismo (Valdez, 2006). No obstante, hay que tener cautela al relacionar votos y sanción a un gobierno. Manuel Alejandro Guerrero confirmó que la ciudadanía mexicana no parecía muy interesada en exigir una mayor rendición de cuentas a sus gobernantes a la hora de votar (Guerrero, 2004). Hay autores que advierten que las elecciones constituyen un mecanismo poco fino para dar a conocer a los representantes que premian y que castigan (Przeworski, Stokes y Manin, 1999).

${ }^{63}$ Boaventura de Sousa Santos aclara que el fascismo se encuentra entre nosotros con varias modalidades y que no es como el fascismo de la primera mitad del siglo XX. El fascismo paraestatal resulta de la usurpación, por parte de poderosos actores sociales, de las prerrogativas estatales de coerción y de regulación social. Se trata de una usurpación completada con la connivencia del Estado. Hay una manipulación discrecional de la inseguridad (Santos, 2005).

64 Habría que precisar que hubo una excepción: las elecciones municipales de Guadalajara. Cuando al candidato panista le llevaron un grueso documento con informaciones para que fueran usadas en una guerra sucia contra su principal contrincante, lo desechó y dijo que prefería no utilizar esa vía para obtener el triunfo (entrevista con José Lévy, 6 de noviembre de 2006). 
contra del voto libre e informado ${ }^{65}$. No se respetó lo básico de la democracia electoral. No hubo información que alentara la deliberación. El panismo no quiso perder las posiciones adquiridas y echó mano de todos los recursos, lícitos e ilícitos, en complicidad con los poderes fácticos para contrarrestar la sanción en las urnas. Se privilegiaron maniobras para engañar. Fue abandonada la vieja tradición democrática del panismo y sus principios, y se conculcó la legitimidad democrática. El voto del odio destruyó tejido social básico para la convivencia. Los partidos se supeditaron al imperio del marketing político. Se fanatizó el voto. Si bien hubo errores en la contabilidad de los votos, también hubo maniobras producto de ese fanatismo que creía librar al país de un mal que se había construido con mentiras.

Si en elecciones anteriores los poderes fácticos ${ }^{66}$ se ponían al servicio del Estado autoritario, en esta ocasión subordinaron al mismo Estado a sus propios intereses. El pionero de la investigación de la democracia en México, Pablo González Casanova, puntualizó: "Las elecciones de 2006 no son unas 'elecciones de Estado' como las anteriores, sino el nuevo tipo de elecciones del Estado-Mundo, transnacional y emergente, que cuenta entre sus 'nódulos' o colaboradores asociados y subordinados a numerosos estados y regímenes políticos de las metrópolis y de las periferias" (González Casanova, 2006). Otros autores, destacando lo que llamaron el fraude a la mexicana, recalcaron que nunca la influencia de estos poderes había degradado tanto a la democracia (Báez, 2006). El Informe de Latinobarómetro correspondiente al año 2006 plantea:

\footnotetext{
${ }^{65}$ Cuando hay ausencia de información se logran preferencias no democráticas (Ovejero et al., 2004).

${ }^{66}$ El informe del Programa de las Naciones Unidas para el Desarrollo (PNUD) sobre la democracia en América Latina ha señalado como poderes fácticos al poder del gran dinero, los medios electrónicos de mayor influencia, la jerarquía católica y el crimen organizado (PNUD, 2004). Raúl Trejo ha dicho que los macropoderes que no atienden a controles ni límites capaces de acotarlos se denominan poderes fácticos. Sostiene que entre los poderes salvajes no regulados se encuentra el de los grandes medios electrónicos. Estos poderes influyen de manera decisiva en la vida de los países y destruyen la democracia porque son poderes abusivos. Recuerda que en una democracia no debería existir ningún poder no controlado (Trejo, 2005).
}

Las razones para considerar una elección fraudulenta son muchas, una puede ser la limpieza de la lucha electoral, otra la percepción de pluralidad que existe en el país, es decir, la posibilidad de las distintas opciones de competir en elecciones, y finalmente el concepto más usual de fraude electoral, que es el de los votos que se produce el día de la elección, ya sea porque se alteran los registros o se alteran los votos. Esto se puede dar porque el registro no es adecuado o porque el Estado no da garantías suficientes de que el proceso se lleva a cabo correctamente [...]. Las formas menos directas del fraude electoral percibidas por la población pueden ser muy masivas en un país y momento determinado (Latinobarómetro, 2006: 17).

En México sólo cuatro de cada diez encuestados consideró que las elecciones habían sido limpias (Latinobarómetro, 2006: 18). Entre los encuestados, 20\% manifestó saber de alguien que en las elecciones presidenciales de 2006 había sido presionado o recibió algo a cambio de votar de determinada manera. "El caso de México, con probadas experiencias de fraude electoral en el pasado, es un ambiente especialmente propicio para la sospecha de fraude en esta elección y para la protesta consecuente" (Latinobarómetro, 2006: 23). Hubo una degradación de la ciudadanía que supuestamente se potenciaba al ejercer el voto, pero al haber sido mayoritariamente manipulable no tuvo la autonomía propia ciudadana y se atentó contra su libertad de decisión. Desde instancias de observación ciudadana independiente se hizo un juicio contundente:

La percepción que, como ciudadanos involucrados en la observación de elecciones, nos queda es que la ciudadanía de baja intensidad se combina con la preservación de la cultura del fraude electoral en todos los partidos contendientes; pero que, en esta ocasión, los partidos y sus candidatos despreciaron y desecharon el largo camino pacífico para lograr una democracia que nos permitiera transitar a la construcción de consensos para lograr una sociedad más justa (Jusidman, 2006).

Los partidos y los poderes constitucionales, al confirmar el desafecto de los ciudadanos manifestado en las anteriores elecciones federales de tres años atrás, en lugar de mejorar sus campañas quedaron atrapados en la lógica del marketing político lejano a la información necesaria que requerían los ciudadanos para ejercer su derecho 
de un voto libre e informado. A su vez, los partidos se diluyeron ante las camarillas del marketing ligadas a los poderes fácticos. El pragmatismo utilitario-electoral desvirtuó a los partidos cuyos miembros están a la caza de cargos y privilegios, lejos de principios y de programas.

Lo más impactante de la coyuntura electoral de 2006, tanto a nivel federal como en el estado de Jalisco, fue que el PAN traicionó a la democracia y le dio la espalda a sus principios fundadores. En 2006 los restos de Efraín González Luna fueron trasladados a la Rotonda de los Jaliscienses Ilustres. González Luna fue el gran ideólogo de Acción Nacional. Durante toda su vida estuvo en contra de la imposición facciosa, contraria a la auténtica representación. Sufrió en carne propia la guerra sucia y el fraude electoral. Se pronunció por instaurar una política limpia, un poder ejercido no como dominio faccioso sino como responsabilidad y servicio. Fue enemigo de la propaganda deformadora. Defendió los valores éticos. Demandó que los recursos públicos no fueran utilizados a favor de un partido. Desenmascaró la forma en que el partido en el poder simulaba hacer una política para todos, pero en realidad burlaba la voluntad y los derechos del pueblo y se apoyaba en la mentira para no soltar el poder. Hacía ver cómo la explotación política de la mentira redundaba en una constante adulteración de la voluntad nacional. Insistía en que la búsqueda de triunfos electorales no justificaba echar mano de la mentira. Enseñaba que el llamado realismo era cínico y productor de desastres, y que nunca había de dejar de lado los imperativos éticos (Alonso, 2003, 2006b). Se presentó así una paradoja. Para crecer, el PAN se empequeñeció. Aumentó puestos de poder y seguidores, pero a costa de reducir su calidad ética a la mínima expresión al renunciar al humanismo político de sus fundadores ${ }^{67}$.

La democracia debería garantizar que el poder fuera controlado por los ciudadanos, pero ha sido usurpada por los poderes fácticos que hacen prevalecer sus agendas. En noviembre de 2006 el Consejo Coordinador Em-

\footnotetext{
${ }^{67}$ El panismo suplantó al priísmo; no liberó del clientelismo ni de la opresión política. Invocando vanamente la ley, desató la fuerza del terror sobre los inconformes y mantuvo la injusticia. Mantuvo algunos enunciados de principios, pero sus prácticas no se compaginan con ellos.
}

presarial llevó a Calderón sus exigencias, lo cual se interpretó como el cobro de servicios prestados durante la elección ${ }^{68}$. Los poderes económicos influyeron en las elecciones al margen de todo control democrático y afectaron la convivencia. Los grandes medios electrónicos indicaron no sólo cuáles eran los problemas atendibles y cuáles las respuestas aceptables, sino quiénes eran elegibles y quiénes rechazables. Los políticos no respondieron a los ciudadanos sino a los poderes fácticos. Se envileció la política y se dinamitó la igualdad política de los ciudadanos (Ovejero et al., 2004). El ambiente fraudulento que impulsaron los poderes fácticos hizo visible el gran déficit en la democracia mexicana. Las elecciones mostraron quién tiene el poder más allá de lo formal, cómo lo ejerce, quiénes son sus beneficiarios y cómo se subordinan los puestos públicos a sus intereses. Así hay un poder que se impone, pero sin legitimidad ni autoridad creíble.

La situación fraudulenta no hace creíbles las promesas democratizadoras provenientes del nuevo gobierno federal. El hecho de que se haya convocado al gabinete al gobernador panista jalisciense Ramírez Acuña demostró cómo a un gobierno emanado de elecciones cuestionadas no le preocupaba cuidar la fama democrática de sus integrantes ${ }^{69}$. Hay una pérdida de legitimidad democrática de las decisiones políticas.

\footnotetext{
${ }^{68}$ Se puede consultar el escrito de Carlos Acosta, "Empresarios, cobro de facturas", aparecido en Proceso, 12 de noviembre de 2006.

${ }^{69} \mathrm{~A}$ esto hay que añadir que quienes contribuyeron económica y políticamente al escenario electoral empezaran a pasar onerosas facturas políticas. La composición del gabinete fue leída como pago de facturas. Nacional e internacionalmente fue criticada la nominación de Ramírez Acuña en la Secretaría de Gobernación. El diario español El País dio así la noticia: "El nombramiento como secretario de Gobernación de México de Francisco Ramírez Acuña, controvertido ex gobernador del estado de Jalisco con fama de halcón, fue recibido con una oleada de críticas por parte de los partidos de oposición, organizaciones de derechos humanos y comentaristas políticos" (29 de noviembre de 2006). Los medios nacionales resaltaron su perfil de poca tolerancia y autoritarismo (La Jornada, El Universal, 29 de noviembre de 2006). Periodistas de El Universal calificaron esa designación como el primer gran error del nuevo presidente. Se recordó que Jalisco fue uno de los estados en donde más impugnaciones hubo por irregularidades electorales. Pese a que los empresarios y la jerarquía eclesiástica alabó esta designación, en Jalisco hubo un plantón de repudio. Organismos de defensa de los derechos humanos señalaron que en el gobierno de Ramírez Acuña las denuncias por tortura se habían disparado $900 \%$. Insis-
} 
No obstante, todo esto ha propiciado una pedagogía de la indignación (Freire, 2006). El ambiente fraudulento rompió un virtual pacto democrático y las protestas rebasaron los límites de tolerancia de la actuación que suponía dicho pacto. Hay minorías activas que no muestran resignación ante lo que califican como fraude. $\mathrm{Hu}-$ bo una gran cantidad de nutridas manifestaciones en la ciudad de México que no aceptaron los resultados oficiales de los comicios presidenciales ${ }^{70}$. En Jalisco el núcleo fue pequeño pero constante ${ }^{71}$. Los que instigaron el voto del miedo temen que se profundice la ansiedad de los excluidos tanto económica como políticamente (Santos, 2005). Las elecciones enfrentaron, por una parte, a los poderosos y sus aliados y, por otra, a los pobres y marginados en una elección clasista e ideologizada. Ha emergido

tieron en que se había dado un retroceso en el ámbito de los derechos humanos. Recordaron que el 24 de noviembre el Comité contra la Tortura, de la ONU, había exigido al gobierno de México que aclarara las violaciones a los derechos humanos en los casos de Atenco, Oaxaca y Guadalajara, y se había quejado de que en México había impunidad en el tema de la tortura. Los organismos defensores de derechos humanos destacaron que el nombramiento de Ramírez Acuña implicaba un mensaje de criminalización de la protesta social y no de velar por la justicia (Mural, 24 de noviembre de 2006 y 4 de diciembre de 2006). La articulista Ivabelle Arroyo puntualizó que su mérito era ser autoritario. Se lamentó que se nombrara a un político nocivo para la frágil democracia. Adelantó que metería a la siguiente administración federal en más problemas de los que pudiera resolver porque ha sido un hombre "que actúa sólo bajo su propia ley" ("La ley de Ramírez Acuña", Mural, 28 de noviembre de 2006). El mensaje de terror, nos dice Márai, es para obligar a la gente a aceptar la atrocidad humana, aquel engaño a que se somete a los ciudadanos mediante la violencia y el fraude (Márai, 2006). ${ }^{70}$ Siempre son menos los que se movilizan que los que votan. Las movilizaciones de protesta fueron encaradas con hostilidad por los grandes medios de comunicación electrónica y hubo una campaña para tratar de imponer la "normalidad fraudulenta" y para desprestigiar a los insumisos. María de las Heras, apoyada en una de sus encuestas, afirmaba que López Obrador había perdido apoyo aun entre los que habían votado por él (Milenio, 19 de noviembre de 2006). Otra encuesta, la de GEA-ISA, indicaba que sólo dos de cada diez apoyaban los actos de protesta de López Obrador (Reforma, 20 de noviembre de 2006). No obstante, esto último equivalía a la misma proporción de los ciudadanos inscritos en las listas nominales que habían votado por Calderón. El número de los que están contra el fraude ha llenado el Zócalo de la ciudad de México en muy variadas fechas. Wallerstein se preguntó: “¿Cómo fue que el vecino de al lado de Estados Unidos llega al punto en que su gobierno es impugnado activa y vigorosamente como ilegítimo, y donde la gente discute si el presidente legal podrá en verdad permanecer en el cargo todo su periodo de seis años, lo que termina con 80 años de relativa estabilidad política?" (Wallerstein, 2006).

${ }^{71}$ Los diversos actos de protesta de jaliscienses reunían desde unos cientos hasta cinco mil participantes. un descontento contra la manera en que se manipula la democracia mexicana. Hay protestas contra un poder ilegítimo impuesto por los poderes fácticos, que no toleraron una propuesta de un capitalismo con más asistencialismo, lo que obligó a quienes aspiraban a ser protegidos por un gobierno de ese tipo a hacer un corrimiento hacia una lucha antineoliberal y a oponerse a los totalitarismos del gran capital trasnacional y de los grandes medios electrónicos mexicanos ${ }^{72}$.

Las elecciones de 2006 evidenciaron una grave y profunda crisis de la democracia mexicana. Como lo mues-

72 En esta forma, el movimiento contra el neoliberalismo se vio aumentado y potenciado por el fraude electoral. Previamente, las luchas contra el neoliberalismo en México se habían configurado en dos grandes vertientes. Una había ido sumando agrupaciones que han centrado su acción en contra de las privatizaciones neoliberales e interpela al poder estatal; la otra, la inspirada por los zapatistas, se ha propuesto, desde lo más olvidado de la sociedad, luchar contra el capitalismo en general y ha roto definitivamente con toda la clase política. Denunciando que el neoliberalismo en México ha acrecentado las desigualdades y concentrado en unos cuantos un inmenso poder económico y político, agrupaciones, sobre todo obreras, integradas en el Frente Sindical Mexicano, en la Unión Nacional de Trabajadores, en la Promotora por la Unidad Nacional contra el Neoliberalismo y en la Red Mexicana frente al Libre Comercio han realizado una gran cantidad de marchas en contra de la privatización de los energéticos, del agua, de la seguridad social y de la educación pública. Han organizado reuniones bajo el nombre de Diálogo Nacional en las que han discutido un proyecto de nación alternativo al neoliberalismo, han elaborado una declaración y un programa mínimo no negociable. Por su parte, el zapatismo se ha propuesto una organización muy amplia y ambiciosa de los marginados y dañados por el neoliberalismo por todo el país. El recorrido de "La Otra Campaña" ha ido convenciendo de que el enemigo común es el capitalismo. Los de abajo no deben pelearse entre ellos, sino enfocar sus baterías contra los responsables de la miseria y de la destrucción. Ante el marketing político que atiborra de mensajes vacíos y mendaces frente a una ciudadanía a la que sólo se le concede el papel de espectador, "La Otra Campaña" obliga a sus constructores a tener que oír a la gente que padece el capitalismo y lo resiste con sus pequeñas luchas cotidianas. Sigue siendo un reto el que estas convergencias alcancen un nivel en el que tengan la capacidad de romper los círculos viciosos de la dispersión y de la fragmentación. Frente a los grandes poderes concentrados de la explotación y de la opresión se necesita la construcción de un nuevo campo para la acción de un movimiento que verdaderamente sacuda todo desde abajo. Ante la vorágine alienadora, la impronta del tiempo indígena ha introducido esa temporalidad amplia y sin prisas de la larga construcción. Hay una verdadera preocupación porque la nueva construcción surja de abajo. Se está cuestionando el consenso social predominante para alcanzar e impulsar otro consenso. Engarzando resistencias se busca un programa que unifique los descontentos. Se ha captado que lo sólo autogestivo sin nexos más amplios no llegará a enfrentar a enemigos muy poderosos y cohesionados. Se necesita una lucha contrahegemónica que, sin anularlos, trascienda los pequeños grupos. Hay ya varias corrientes en contra del neoliberalismo y tienen el reto de construir una nueva fuerza con impulso ético. 
tra Wallerstein, basado en Prigogine, en una situación de crisis sistémica se presentan bifurcaciones hacia dos o más soluciones posibles (Wallerstein, 2005). El informe sobre la democracia en América Latina del Programa de las Naciones Unidas para el Desarrollo (PNUD) mostraba la paradoja de la existencia de la democracia electoral al mismo tiempo que un creciente descontento debido a la aguda pobreza y desigualdad que atenta en contra de la democracia integral (compuesta por los derechos civiles, políticos y sociales) (PNUD, 2004). Las elecciones mexicanas de 2006 mostraron que ha habido un peligroso retroceso. Persiste la peligrosa situación de falta de democracia social, pero se le ha añadido la carencia de la legitimidad en lo electoral. Se perdió hasta la democracia mínima ${ }^{73}$. Una opción es la reconstrucción profunda y total de una democracia que sea integral. Esto sólo puede responder a un proyecto basado en la extensión del ejercicio de derechos, que recomponga lo electoral y que se extienda hacia una plural y creativa construcción de una democracia que, partiendo de lo electoral, lo trascienda (Dagnino et al., 2006).

\section{Bibliografía}

Alonso, Jorge (coord.), 2002, Un antidemocrático estilo personal de gobernar, mimeo.

__ 2003, Miradas sobre la personalidad política de Efraín González Luna, Universidad de Guadalajara, Guadalajara.

_, 2006a, La acuitada coyuntura mexicana, Universidad de Guadalajara, Guadalajara.

—_, 2006b, Efraín González Luna, el hombre, Instituto Cultural Ignacio Dávila Garibi, Guadalajara.

Arroyo, Ivabelle, 2005, "Vientos opacos", Mural, 29 de noviembre.

Aziz, Alberto, 2003, "Problemas de primera y segunda generación en la democracia regional en México", Espiral, núm. 27, mayo-agosto, pp. 99-125.

Báez, René, 2006, "Elecciones de nuevo tipo y corrupción sistémica”, Firgoa, noviembre, <firgoa.usc.es $>$.

\footnotetext{
${ }^{73}$ Anteriormente se criticaban las fallas en la democracia política y la democracia social, pero se creía que la democracia electoral era una asignatura cubierta. Con las elecciones de 2006 se evidenció que hubo graves retrocesos hasta en la democracia electoral. Para lograr una democracia integral se requiere ahora un esfuerzo muy grande.
}

Cobián, Felipe, 2006, "Vocación represora”, Proceso, 3 de diciembre.

Cortés, Marco Antonio, 2005, “Abstencionismo y participación cívica y legitimidad insititucional en Jalisco”, en Víctor Alejando Espinoza y Luis Miguel Rionda (coords.), Después de la alternancia: elecciones y nueva competitividad, Universidad Autónoma Metropolitana-Azcapotzalco, México, pp. 325-350.

Dagnino, Evelina, Alberto Olvera y Aldo Panfichi (coords.), 2006, La disputa por la construcción democrática en América Latina, Centro de Investigaciones y Estudios Superiores en Antropología Social, México.

Freire, Paulo, 2006, Pedagogía de la indignación, Moraria, Madrid.

González Casanova, Pablo, 2006, "Esto no es democracia”, La Jornada, 12 de julio.

Guerrero, Manuel Alejandro, 2004, México: la paradoja de su democracia, Universidad Iberoamericana, México.

Jusidman, Clara, 2006, "El discurso de la desigualdad en la contienda electoral", XX Encuentro Internacional de Ciencias Sociales, Feria Internacional del Libro, Guadalajara.

Latinobarómetro, 2006, Informe 2006, <www.latinoabarometro.com>.

Márai, Sándar, 2006, Tierra, tierra, Salamandra, Barcelona.

Martín, Rubén, 2006, “El legado de Ramírez Acuña”, Público, 23 de noviembre.

Martín Rubén y Jorge Regalado, 2006, “Jalisco 2005: contradicciones y paradojas de la alternancia política y el desarrollo económico", en Jorge Alonso, La acuitada coyuntura mexicana, Universidad de Guadalajara, Guadalajara, pp. 237-272.

Mattelart, Armand, 2006, "Entrevista”, La Jornada, 9 de noviembre.

Ovejero Félix, José Luis Martí y Roberto Gargarella (coords.), 2004, Nuevas ideas republicanas, Paidós., Barcelona

PNUD, 2004, La democracia en América Latina. Hacia una democracia de ciudadanos y ciudadanas, Aguilar, Buenos Aires.

Przeworski, Adam, Susan Stokes y Bernard Manin, 1999, Democracy, Accontability and Representation, Cambridge University Press, Cambridge.

Santos, Boaventura de Sousa, 2005, Reinventar la democracia, FLACSO, Buenos Aires.

Trejo, Raúl, 2005, Poderes salvajes. Mediocracia sin contrapesos, Cal y Arena, México.

Valdez, Andrés, 2006, “Lecturas de la elección”, Público, 15 de julio.

Wallerstein, Immanuel, 2005, Las incertidumbres del saber, Gedisa, Barcelona.

-,2006, "La turbulencia mexicana: ¡levantamiento o guerra civil?”, La Jornada, 21 de diciembre. 